\title{
PPAR Beta/Delta and the Hallmarks of Cancer
}

\author{
Nicole Wagner *(D) and Kay-Dietrich Wagner ${ }^{(B)}$ \\ Université Côte d'Azur, CNRS, INSERM, iBV, 06107 Nice, France; kwagner@unice.fr \\ * Correspondence: nwagner@unice.fr; Tel.: +33-493-377665
}

Received: 20 April 2020; Accepted: 1 May 2020; Published: 4 May 2020

\begin{abstract}
Peroxisome proliferator-activated receptors (PPARs) belong to the nuclear hormone receptor family. Three different isoforms, PPAR alpha, PPAR beta/delta and PPAR gamma have been identified. They all form heterodimers with retinoic $\mathrm{X}$ receptors to activate or repress downstream target genes dependent on the presence/absence of ligands and coactivators or corepressors. PPARs differ in their tissue expression profile, ligands and specific agonists and antagonists. PPARs attract attention as potential therapeutic targets for a variety of diseases. PPAR alpha and gamma agonists are in clinical use for the treatment of dyslipidemias and diabetes. For both receptors, several clinical trials as potential therapeutic targets for cancer are ongoing. In contrast, PPAR beta/delta has been suggested as a therapeutic target for metabolic syndrome. However, potential risks in the settings of cancer are less clear. A variety of studies have investigated PPAR beta/delta expression or activation/inhibition in different cancer cell models in vitro, but the relevance for cancer growth in vivo is less well documented and controversial. In this review, we summarize critically the knowledge of PPAR beta/delta functions for the different hallmarks of cancer biological capabilities, which interplay to determine cancer growth.
\end{abstract}

Keywords: peroxisome proliferator-activated receptor; angiogenesis; proliferation; metastasis; immortality; resistance to cell death; growth suppressors; immune system; cellular metabolism

\section{Introduction}

Peroxisome proliferator-activated receptors (PPARs) belong to the group of nuclear receptors. They exist in three different isoforms: PPAR $\alpha$ (NR1C1), PPAR $\beta / \delta$ (NR1C2) and PPAR $\gamma$ (NR1C3). They heterodimerize with RXR; and upon ligand binding act mainly as transcriptional regulators of specific target genes. Dependent on the tissue distribution, cofactors and availability of ligands, PPARs exert multiple functions (reviewed in [1]). PPAR $\alpha$ is mainly expressed in liver, heart, brown adipose tissue, kidney and intestine and regulates energy homeostasis by activation of fatty acid catabolism and stimulation of gluconeogenesis [2]. PPAR $\beta / \delta$ is more or less ubiquitously expressed with some species differences, while PPAR $\gamma$ is expressed in white and brown adipose tissue, the gut and immune cells [1]. Endogenous ligands for PPARs are fatty acids, triglycerides, prostacyclins, prostaglandins and probably retinoic acid. Although varies different binding sites for PPARs in target genes have been reported, they share in general as a response element a direct repeat of the sequence AGGTCA, spaced by a single nucleotide, which was originally identified for PPAR $\alpha$ (reviewed in [1]). Thus, in case more than one of the receptors is expressed in a certain cell-type, one could expect cross talk in response to endogenous or pan-PPAR pharmacological agonists. Specific agonists for PPAR $\alpha$ are used classically for the treatment of dyslipidemia and agonists for PPAR $\gamma$ are insulin sensitizers to treat patients with type 2 diabetes. Currently, no PPAR $\beta / \delta$ activators or antagonists are in official clinical use. A recent review summarized novel developments regarding patents for PPAR modulators and possible novel clinical indications [3]. Clinical evidence for the use of PPAR agonists and antagonists is reviewed in [4]. Toxicological aspects and side effects of PPAR modulators have been reviewed 
recently [5]. Increasing interest focuses on potential implications of PPARs in cancer. The major clinical trials database (https://clinicaltrials.gov) lists one clinical trial for a PPAR $\alpha$ antagonist for treatment of multiple kinds of cancer, 24 trials for modulators of PPAR $\gamma$ for cancer treatment, but none for PPAR $\beta / \delta$. The human protein atlas (https://www.proteinatlas.org/ENSG00000112033-PPARD/pathology) lists low cancer type specificity, but detection of PPAR $\beta / \delta$ in all cancer types. A current major limitation for the investigation of PPAR $\beta / \delta$ expression in human cancer samples compared to healthy tissues is the quality of commercially available antibodies. In agreement with this, large differences for PPAR $\beta / \delta$ RNA and protein levels in tumors are noted in the human protein atlas. The protein expression is globally described, but not annotated to certain cell types in the different tumors. Correlations of tumor PPAR $\beta / \delta$ expression with patients outcome have been reviewed recently [6].

Earlier experimental results concerning the role of PPAR $\beta / \delta$ activation for cancer growth were completely controversial with one study showing that pharmacological activation with GW501516 enhanced tumor growth in Apc(min) mice [7], while another study in the same year in the same journal showed enhanced tumor growth in Apc(min) mice crossed with PPAR $\beta / \delta$ knockout mice [8]. Many studies using different cell models have been published afterwards. Several aspects of PPAR $\beta / \delta$ function with relevance for cancer growth have been reviewed recently [1,5,6,9-11].

On a global view, tumor progression is determined by the interplay of cancer cell proliferation, angiogenesis, resisting cell death, evading growth suppressors, activating invasion and metastasis, enabling replicative immortality, deregulating cellular metabolism and avoiding immune destruction, which was defined by Hanahan and Weinberg as the didactic concept of the "hallmarks of cancer" [12,13]. We will follow here this concept and review the knowledge of PPAR $\beta / \delta$ function for the different hallmarks of cancer capabilities.

\section{PPAR $\beta / \delta$ and Cell Proliferation}

Most published papers focused on tumor growth-promoting or tumor-inhibiting actions of $\operatorname{PPAR} \beta / \delta$. Unfortunately, only few manuscripts distinguished between direct effects on cell proliferation and secondary effects, which might affect tumor growth. Thus, for simplification, we will summarize in this chapter the published results on cell proliferation as well as on general tumor growth. Table 1 summarizes published effects of PPAR $\beta / \delta$ on cell proliferation and tumor growth.

Table 1. Effects of PPAR $\beta / \delta$ on cell proliferation and tumor growth.

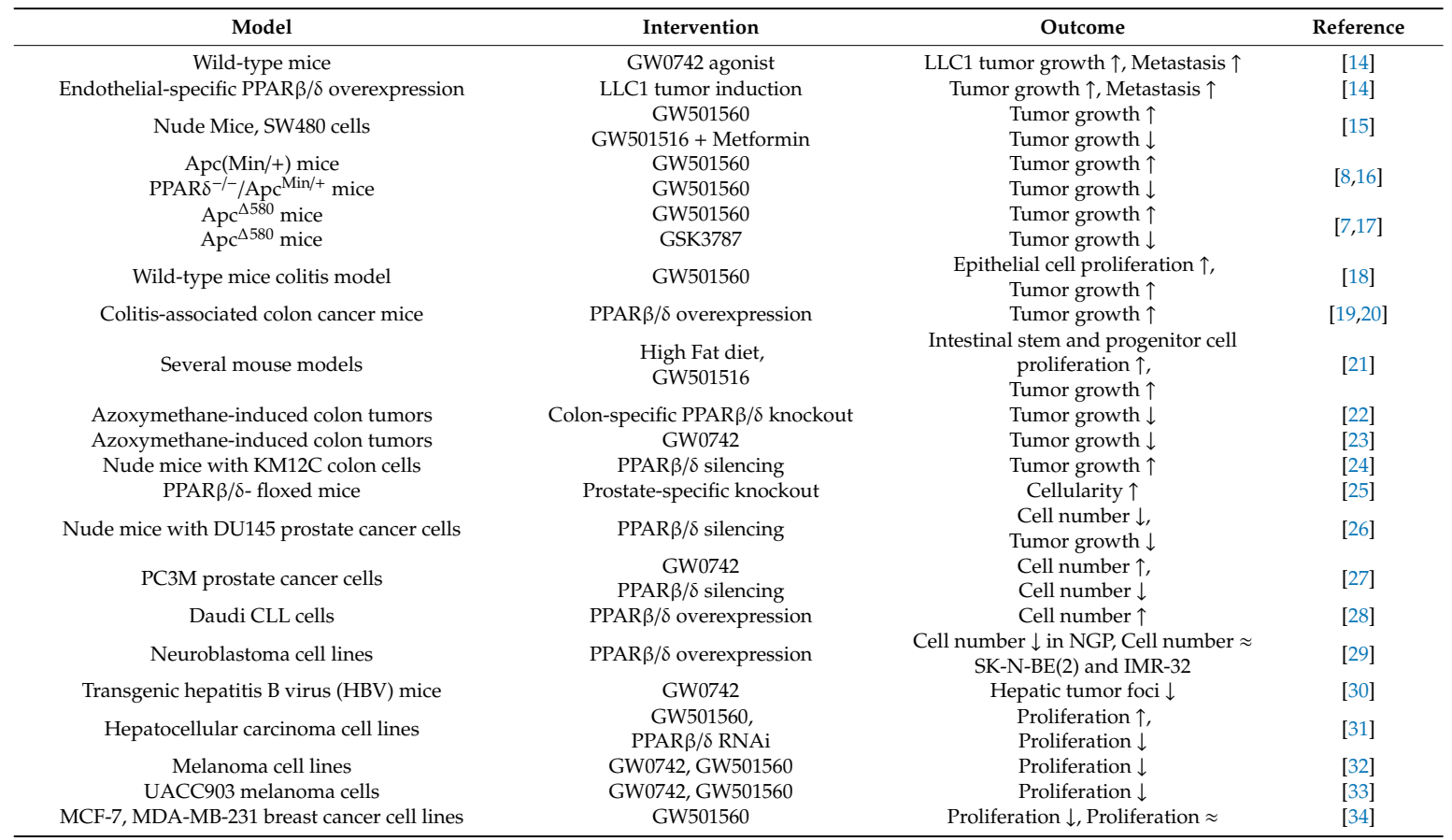


Table 1. Cont.

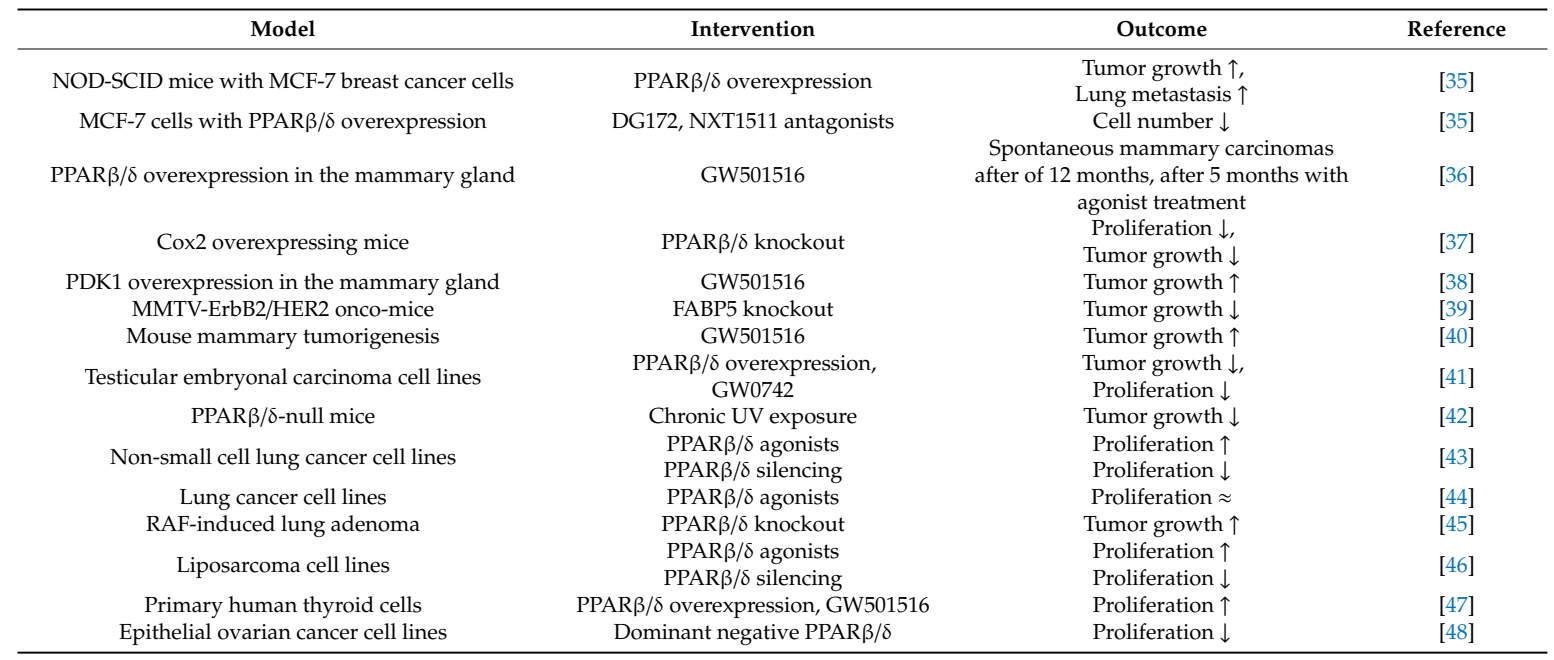

$\uparrow$ Increase; $\downarrow$ decrease; $\approx$ not significantly different; CLL: chronic lymphocytic leukemia; Apc: Familial Adenomatous Polyposis gene mutated; GW501516, GW0742—specific PPAR $\beta / \delta$ agonists; DG172, NXT1511, GSK3787-PPAR $\beta / \delta$ antagonists.

It has been shown that the PPAR $\beta / \delta$ agonist GW501560 increased VEGF expression in tumor cell lines [16] and promoted tumorigenesis in Apc(Min/+) mice $[7,16]$ linking tumor cell growth and angiogenesis in the gut. Genetical disruption of PPAR $\beta / \delta$ in colon epithelial cells resulted in a lower incidence of azoxymethane-induced colon tumors and reduced VEGF expression [22]. Unfortunately, vessel formation has not been analyzed in detail in these models [16]. In the same azoxymethane-induced colon tumor model, also reduced tumor growth in response to GW0742, which was abolished by PPAR $\beta / \delta$ knockout [23] and a general reduced colon tumor growth in PPAR $\beta / \delta$ knockout mice [8] have been reported. This discrepancy remains unexplained. PPAR $\gamma$ and PPAR $\beta / \delta$ activation of VEGF and cyclooxygenase-2 (COX2) was confirmed in in the colorectal tumor cell lines SW480 and HT29 [49]. Curiously, that opposite regarding cancer growth and VEGF regulation was described using the KM12C colon cancer cell line with silencing of PPAR $\beta / \delta$ in mouse xenograft models [24]. Whether this reflects an unusual behavior of this specialized cell line remains to be determined. The tumor promoting action of GW501516 in Apc mice was confirmed recently and extended by the findings that the PPAR $\beta / \delta$ antagonist GSK3787 suppressed tumorigenesis. PPAR $\beta / \delta$ expression was significantly higher in human colorectal cancers compared to adenomatous polyps and normal mucosa [50] and also in the malignant cells-invasive front versus their paired tumor centers and adenomas-and proinvasive pathways (connexin 43, PDGFRb, AKT1, EIF4G1 and CDK1) were upregulated in response to PPAR $\beta / \delta$ stimulation [17]. Again, the opposite result has also been published for human and mouse tumor samples [51], while another important report using human colorectal cancer samples confirmed high expression of PPAR $\beta / \delta$ and COX2, which was correlated with the incidence of liver metastasis and identified as significant independent prognostic factor [52]. In colitis-associated colon cancer mouse models, PPAR $\beta / \delta$ overexpression promoted tumorigenesis in mice [20] and increased IL-6 expression and STAT3 phosphorylation, whereas concomitant 15-Lipoxygenase-1 expression in colonic epithelial cells suppressed these effects [19]. In an elegant study using different mouse lines, Beyaz et al. showed that high fat diet (HFD) via activation of PPAR $\beta / \delta$ augments the numbers and function of intestinal stem and progenitor cells. Pharmacological activation of PPAR $\beta / \delta$ using GW501516 recapitulated the effects of HFD on these cells. PPAR $\beta / \delta$ activation in the setting of a loss of the APC tumor suppressor gene allowed stem and progenitor cells to initiate tumorigenesis [21], which is in agreement with the studies mentioned above.

Regarding mammary neoplasia, Yuan et al. [36] showed in transgenic animals that activation of PPAR $\beta / \delta$ in the mammary epithelium resulted in progressive histopathologic changes that culminated in the appearance of estrogen receptor- and progesterone receptor-positive and ErbB2-negative 
infiltrating ductal carcinomas after 12 months in transgenic animals, while treatment with GW501516 shortened the interval until tumor appearance to 5 months. Histologically, Ki-67 expression was increased demonstrating enhanced proliferation of the epithelial cells, and several metabolic changes were observed (see below). Additionally, in animals with 3-phosphoinositide-dependent kinase-1 (PDK1) overexpression in mammary epithelium, GW501516 accelerated tumorigenesis, which was more pronounced in mice with PDK1 overexpression [38]. This is in agreement with many other reports as PDK1 overexpression resulted in an increase in PPAR $\beta / \delta$ expression and profound metabolic changes. Furthermore, GW501516 increased PPAR $\beta / \delta$ and PDK1 expression in mammary tumors [40]. In MMTV-ErbB2/HER2 onco-mice, knockout of FABP5, which shuttles ligands from the cytosol to nuclear PPAR $\beta / \delta$ was sufficient to reduce mammary tumorigenesis highlighting the importance of this molecule and endogenous PPAR $\beta / \delta$ ligands for cancer growth [39]. On the molecular level, epidermal growth factor receptor ligands signal through the ERK and the phophatidylinositol-3-kinase cascades to activate the transcription factor NF-kappaB. NF-kappaB increases via direct transcriptional activation the expression of FABP5 in MCF-7 breast cancer cells, which stimulates proliferation [53]. In Cox-2 overexpressing mice, mammary tumorigenesis was increased, which could be reverted by crossing them with PPAR $\beta / \delta$ knockout mice [37]. In severely immunocompromised mice, MCF-7 breast cancer cells with overexpression of PPAR $\beta / \delta$ produced bigger tumors and more metastasis compared to wild-type cells. Treatment of MCF-7 cells with PPAR $\beta / \delta$ antagonists in culture reduced significantly the number of these cells $[35,54]$.

Martín-Martín et al. showed an opposite result for prostate carcinoma. PPAR $\beta / \delta$ mRNA was downregulated in prostate cancer specimens compared to benign prostate hyperplasia samples; and prostate epithelium-specific knockout of PPAR $\beta / \delta$ increased cellularity. Additional supporting evidence was obtained by the generation of different overexpression or silencing clones from different human prostate cancer cell lines. Mechanistically, PPAR $\beta / \delta$ exerted its activity in a DNA binding-dependent and ligand-independent manner, which involved regulation of the secretory trefoil factor family member 1 [25]. To which extend the stable cell clones and mice exposed during the entire lifespan to the Cre corresponding to tumor development in humans in vivo remains to be determined. In contrast, silencing of PPAR $\beta / \delta$ in prostate cancer cell lines inhibited tumor cell proliferation and tumor growth, which was attributed to activation of the ABCA1 cholesterol transporter-Caveolin1-TGF $\beta$ receptor signaling axis [26]. A similar observation in prostate cancer cells was published by Morgan et al., identifying fatty acid binding protein 5 (FABP5) as a direct target gene of PPAR $\beta / \delta$ [27].

Overexpression of PPAR $\beta / \delta$ decreased the cell number in neuroblastoma NGP, but not in SK-N-BE(2) and IMR-32 cell clones. In xenograft models, PPAR $\beta / \delta$ overexpression reduced tumor growth in NGP cell clones, but to a lesser extent in SK-N-BE(2) and IMR-32 cell clones [29]. As the level of overexpression of PPAR $\beta / \delta$ was highest in NGP cells, it is difficult to judge whether the different outcome is due to the different cell lines used or a response to the different levels of PPAR $\beta / \delta$ overexpression. Whether the results correspond to neuroblastoma pathogenesis in vivo remained an open question. A comparable observation was published by the same group when using testicular embryonal carcinoma cell clones with PPAR $\beta / \delta$ overexpression and the agonist GW0742 [41].

In transgenic hepatitis B virus (HBV) mice, long term treatment with the PPAR $\beta / \delta$ agonist GW0742 reduced the number of hepatic tumor foci. Based on reduced expression of cyclin D1 and c-Myc, a reduction in tumor cell proliferation has been proposed [30]. In human hepatocellular carcinoma cell lines, GW501516 increased proliferation, while RNAi against PPAR $\beta / \delta$ inhibited cell growth. $\operatorname{PPAR} \beta / \delta$ activation up-regulates the expression of cyclooxygenase (COX)-2, a rate-limiting enzyme for prostaglandin synthesis and tumor growth in hepatocellular cancer lines [31].

Chronic exposure to ultraviolet light (UV) induced PPAR $\beta / \delta$ activity in the skin of mice. Increased $\operatorname{PPAR} \beta / \delta$ activity directly stimulated Src expression, increased Src kinase activity and enhanced the EGFR/Erk1/2 signaling pathway, resulting in increased epithelial-to-mesenchymal transition (EMT) marker expression. PPAR $\beta / \delta$-null mice developed fewer and smaller skin tumors. Furthermore, topical application of the PPAR $\beta / \delta$ antagonist GSK0660 prevented UV-dependent Src stimulation; and the 
expression of PPAR $\beta / \delta$ positively correlated with the expression of SRC and EMT markers in human skin squamous cell carcinoma (SCC) highlighting the clinical relevance of these findings [42]. Another report claimed that the agonist GW0742 delayed chemical induced skin carcinogenesis; combination of GW0742 and the COX2 inhibitor nimesulide resulted in a further decrease of tumor multiplicity in wild-type mice, but not in PPAR $\beta / \delta$-null mice [55]. Given that the graphs in the different groups for tumor incidence, multiplicity and size look comparable and no statistical information is provided, it is difficult to follow this line of evidence, which is in sharp contrast to many other published papers. Even more surprising, the same authors reported earlier for a comparable model no effect of GW0742 on chemical induced skin carcinogenesis [56], or no combined effects for GW0742 and the COX2 inhibitor nimesulide in induced colon cancers [57] or independence of the COX2 inhibitor effects on PPAR $\beta / \delta$ [58].

High PPAR $\beta / \delta$ expression was detected in human melanoma compared to normal skin [32]. PPAR $\beta / \delta$ activation using GW0742 or GW501516 inhibited proliferation of different melanoma cell lines [32,33], which was due to direct transcriptional repression of the Wilms' tumor suppressor WT1 and its downstream target genes zyxin [59] and nestin [59-61].

In non-small cell lung cancer (NSCLC) cell lines, PPAR $\beta / \delta$ activation increased proliferation and survival, while PPAR $\beta / \delta$ knock-down reduced viability and increased apoptosis. As reported for colon cancer, PPAR $\beta / \delta$ agonists induced VEGF transcription in NSCLC cell lines. Furthermore, increased expression of PPAR $\beta / \delta$ and VEGF in human non-small cell lung cancer samples compared to normal lung tissues has been detected [43,62]. In contrast, a study using only two lung cancer cell lines in vitro, did not find any effects on cell proliferation in response to PPAR $\beta / \delta$ activation [44]. In a transgenic mouse model of RAF-induced lung adenoma, tumor growth in mice lacking one or both alleles of PPAR $\beta / \delta$ was reported to be increased [45]. However, the histological analysis performed in this model was superficial and statistical information lacking.

We showed in liposarcoma cell lines that PPAR $\beta / \delta$ activation increases proliferation, which is abolished by a PPAR $\beta / \delta$-siRNA or a specific PPAR $\beta / \delta$ antagonist. These effects were mediated via direct transcriptional repression of leptin by PPAR $\beta / \delta$. PPAR $\beta / \delta$ was highly expressed in liposarcoma compared to lipoma and correlated with increased proliferation in human tumor samples [46].

PPAR $\beta / \delta$ was increased in benign and malignant human thyroid tumors and correlated with the proliferation marker Ki67. Overexpression of PPAR $\beta / \delta$ in thyroid cells and treatment with GW501516 increased cell proliferation in a cyclin E1-dependent manner. Specificity of the findings was proven by reduction of cyclin E1 expression and cell proliferation in response to RNAi against PPAR $\beta / \delta$ [47].

Epithelial ovarian cancer cell lines expressed high levels of PPAR $\beta / \delta$. Inhibition of PPAR $\beta / \delta$ reduced epithelial ovarian cancer cell proliferation and reduced tumor growth in vivo. Mechanistically, aspirin, a nonsteroidal anti-inflammatory drug that preferentially inhibits COX-1, compromised PPAR $\beta / \delta$ function and cell growth by inhibiting extracellular signal-regulated kinases $1 / 2$ [48].

Although still some controversies exist, PPAR $\beta / \delta$ expression has been documented in a broad variety of different tumor samples and cancer cell lines. In the majority of published reports, PPAR $\beta / \delta$ activation or overexpression was associated with increased cancer cell and tumor growth, some opposite results may be explained by use of different clonal cell lines or different genetic backgrounds and models in mice.

\section{PPAR $\beta / \delta$ and Angiogenesis}

In contrast to PPAR $\alpha$ and PPAR $\gamma, \operatorname{PPAR} \beta / \delta$ is a proangiogenic member of the PPAR family [63]. Vascular cell expression of PPAR $\beta / \delta$ has first been reported in the late 90 s by Xin et al., 1999, using mRNA analysis [64] and Bishop-Bailey and Hla, 1999, employing Northern blot techniques [65]. In addition, PPAR $\beta / \delta$ expression in vascular smooth muscle cells had been observed by Bishop-Bailey in 2000 [66].

However, no specific functions of PPAR $\beta / \delta$ in the vasculature were discovered at that time, due to the lack of specific ligands. The first synthetic PPAR $\beta / \delta$ and PPAR $\gamma$ non-thiazolidinedione agonist 
L-165041 was established in 1999 [67], followed later by the highly selective PPAR $\beta / \delta$ agonists GW0742 and GW501516 [68].

A first report shading light on the function of PPAR $\beta / \delta$ in vascular cells appeared in 2001 . Hatae and colleagues observed that prostacyclins induce apoptosis via PPAR $\beta / \delta$ activation in HEK293 cells whereas endothelial cells, which express cytoplasmic prostacyclin receptors are protected from apoptosis. They concluded that prostacyclin-dependent receptor activation results in increased cAMP levels in endothelial cells, which protects from apoptosis while direct prostacyclin activation of PPAR $\beta / \delta$ in cells lacking cytoplasmic prostacyclin receptors is proapoptotic [69]. A second investigation focusing on endothelial cell apoptosis demonstrated a protective action of L-165041 as well as of carbaprostacyclin (cPGL2) upon $\mathrm{H}_{2} \mathrm{O}_{2}$ induced apoptosis. Both substances increased expression of PPAR $\beta / \delta$; knockdown of PPAR $\beta / \delta$ abrogated the apoptosis diminishing effects of both agents. As the molecular mechanism of this apoptosis protective function of PPAR $\beta / \delta$ in endothelial cells, the authors proposed the direct transcriptional activation of 14-3-3alpha protein, a cytosolic protein involved in apoptosis protection, by $\operatorname{PPAR} \beta / \delta$ [70]. A later study further added activation of endothelial 14-3-3epsilon protein by PPAR $\beta / \delta$ agonists to the antiapoptotic role [71]. Non-steroidal anti-inflammatory drugs (NSAIDs) can induce endothelial cell apoptosis by disconcerting these transcriptional pathways [72].

$\operatorname{PPAR} \beta / \delta$ agonists became of particular interest in vascular biology as they were shown to potently inhibit vascular inflammation and reduce atherosclerosis [73]. They inhibit tumor necrosis factor alpha $(\mathrm{TNF} \alpha)$ mediated endothelial inflammation, evidenced by decreased expression of vascular cell adhesion molecule-1 (VCAM-1), monocyte chemotactic protein-1 (MCP-1) expression and inhibition of monocyte binding of TNF $\alpha$ stimulated endothelial cells treated with the PPAR $\beta / \delta$ agonist L-165041 [74]. It has been proposed that PPAR $\beta / \delta$ further controls inflammation via a ligand-dependent interaction with the transcriptional repressor BCL- 6 . In the absence of other ligands, PPAR $\beta / \delta$ binds BCL- 6 . When activated with a PPAR $\beta / \delta$ ligand, BCL-6 is released and can suppress proinflammatory pathways $[65,75]$. Later reports confirmed the anti-inflammatory effect of PPAR $\beta / \delta$ in endothelium $[76,77]$. PPAR $\beta / \delta$ also inhibits vascular smooth muscle inflammation by transcriptional activation of transforming growth factor (TGF) $\beta 1$. The decreased MCP- 1 expression induced by PPAR $\beta / \delta$ was shown to be mediated by the effector of TGF- $\beta 1$, Smad3 [78].

Activation of PPAR $\beta / \delta$ has also been reported to prevent endothelial dysfunction by reducing oxidative stress [79]. In diabetic mice, PPAR $\beta / \delta$ activation mediated through phosphatidylinositol 3-kinase (PI3K) and Akt an increase of endothelial nitric oxide synthase (eNOS) activity and nitric oxide (NO) production and improved endothelium-dependent relaxation parameters [80]. In high glucose induced impairment of insulin signaling, PPAR $\beta / \delta$ activation restores endothelial function in part through pyruvate dehydrogenase kinase (PDK) 4 activation, thus preserving the insulin-Akt-eNOS pathway impaired by high glucose [81].

Despite its anti-inflammatory and anti-atherosclerotic functions in the vasculature, PPAR $\beta / \delta$ is a major factor for acute vascular hyperpermeability and vasodilatation, key features of allergic reactions, which can lead to lethal systemic anaphylaxis. The group of Michalik recently demonstrated that selective vessel-specific deletion of PPAR $\beta / \delta$ is sufficient to inhibit VEGF or IgE- induced acute vascular hyperpermeability and vasodilatation, most likely due to activity modulation of kinase pathways and destabilization of cell-to-cell adherens junctions. Inhibition of PPAR $\beta / \delta$ should be considered as a therapeutic approach in acute allergic and inflammatory diseases with disturbed endothelial integrity [82].

The first detailed report about the proangiogenic function of PPAR $\beta / \delta$ appeared in 2007. The selective PPAR $\beta / \delta$ ligand GW501516 was tested at this time in phase II clinical trials for the treatment of dyslipidemia. Using a variety of in vitro and ex vivo approaches, the authors clearly demonstrated that PPAR $\beta / \delta$ induces endothelial cell migration, proliferation and tube formation. They further described an increase of vascular endothelial growth factor (VEGF) expression upon activation of PPAR $\beta / \delta$ and already cautioned against possible negative side effects of agonist treatment in patients 
susceptible for "angiogenic diseases", such as elderly persons prone to cancer incidence or diabetic individuals with retinopathies [83].

In vivo studies further showed that pharmacological activation with GW0742 as well as muscle specific transgenic overexpression of PPAR $\beta / \delta$ resulted in a rapid increase of capillary density and oxidative fiber numbers in skeletal muscle, resembling the muscular phenotype induced by regular physical training. It had been proposed that the observed effects were the calcineurin-nuclear factor of activated T cells (NFAT) pathway dependent, as inhibition of calcineurin by cyclosporine A (CsA) totally abolished the observed effects of pharmacological activation of PPAR $\beta / \delta$ [84]. Our group further demonstrated the function of PPAR $\beta / \delta$ in physiological vascularization. Treatment of mice with the agonist GW0742 resulted in rapid cardiac growth and vascularization without functional impairment as reflected by normal echocardiographic parameters. The cardiac hypertrophy accompanied by intensive vascularization resembled the cardiac phenotype obtained by long-term voluntary exercise. As the underlying molecular mechanism of this PPAR $\beta / \delta$ action, we identified the calcineurin-nuclear factor of activated T cells (NFAT) pathway [85]. However, it was unclear if the observed increased vascularization was a secondary effect of the myocardial hypertrophy or if the induction of cardiac growth was due to the increased angiogenesis. We therefore generated conditional mice with inducible vessel specific overexpression of PPAR $\beta / \delta$ and observed that vascular overexpression of PPAR $\beta / \delta$ was sufficient to induce a rapid cardiac hypertrophy. Nevertheless, the increased angiogenesis did not ameliorate cardiac function after myocardial infarction [86]. Similar observations were made using pharmacological activation of PPAR $\beta / \delta$ after myocardial infarction; also in this setting the increase in angiogenesis did not ameliorate the clinical outcome [87]. The proangiogenic function of PPAR $\beta / \delta$ was also exploited in other therapeutic approaches in ischemic cardiovascular diseases. Bone marrow derived endothelial progenitor cells (EPCs) represent an interesting path in the therapy of ischemic diseases, but due to their low number their clinical use is limited. Han and colleagues investigated the effects of PPAR $\beta / \delta$ agonists GW501516 or L-165041 on EPCs and found an increase of angiogenic EPC properties including increased migration, proliferation and tube formation in response to activation of PPAR $\beta / \delta$. These effects were phosphatidylinositol 3-kinase/Akt pathway dependent. Systemic administration of PPAR $\beta / \delta$ agonists led to an increase of hematopoietic stem cells in bone marrow and blood as well as to an enhanced vascularization in ischemic hindlimb models and corneal neovascularization in vivo [88].

The therapeutic potential of PPAR $\beta / \delta$ modulation on aspects of ocular neovascularization, a common feature of premature or diabetic retinopathy, as well as age-related macular degeneration, the leading causes of irreversible blindness, was studied using human retinal microvascular endothelial cells (HRMEC) and in vivo models of oxygen-induced retinopathy (OIR). The authors demonstrated a stimulation of ocular vascularization with PPAR $\beta / \delta$ activation. Furthermore, using the selective PPAR $\beta / \delta$ antagonist GSK0660 [89], the potential therapeutic utility of PPAR $\beta / \delta$ inhibition was proven. GSK0660 decreased HRMEC migration, proliferation, and tube formation and neovascularization in OIR [90].

The effects of PPAR $\beta / \delta$ on tumor angiogenesis were first investigated in 2007. Employing B16 melanoma and LLC1 (Lewis lung carcinoma) tumor cell inoculated in PPAR $\beta / \delta^{-/-}$mice, Müller-Brüsselbach and colleagues demonstrated cancer vascularization defects and diminished tumor blood flow, resulting in reduced tumor growth in animals lacking PPAR $\beta / \delta$. In contrast to the report from Piqueras and colleagues [83], the authors observed a hyperproliferative state of endothelial cells, leading to the formation of immature and dysfunctional microvessels upon deletion of PPAR $\beta / \delta$. On a molecular level, decreased expression of the antiproliferative cyclin-dependent kinase inhibitor $1 \mathrm{C}\left(\mathrm{Cdkn1 \textrm {c } )}\right.$ was observed in PPAR $\beta / \delta^{-/-}$cells isolated from Matrigel plugs, which might explain the proliferative immature state of PPAR $\beta / \delta^{-/-}$endothelium [91].

However, in a second study from this group, diminished expression of chloride intracellular channel protein 4 (Clic4) and increased expression of cellular retinol binding protein 1 (Crbp1) were observed in PPAR $\beta / \delta^{-/}$fibroblasts and endothelial cells as compared to wildtype cells [92]. Clic4 
promotes endothelial cell proliferation, capillary network and lumen formation [93], whereas Crbp1 binding retinoids in contrast favors growth arrest and differentiation [94]. This is in discrepancy to the observed hyperproliferative state of PPAR $\beta / \delta^{-/-}$endothelial cells observed by the group of Müller-Brüsselbach [91] and fits to the conclusions made by Piqueras and colleagues that PPAR $\beta / \delta$ stimulates endothelial cell proliferation [83].

An important study further confirmed the strong implication of PPAR $\beta / \delta$ in proangiogenic stimulation favoring tumor progression. Abdollahi and coworkers aimed to identify genes involved in the "angiogenic switch", the shift of an angiogenic balance to a proangiogenic state, one hallmark of cancer progression. Human microvascular cells were submitted to proangiogenic stimuli and subsequent cDNA arrays performed to identify differentially expressed genes upon proangiogenic stimulation. Further selection of genes based on their involvement in the angiogenic network identified PPAR $\beta / \delta$ as a "hubnode" in the "angiogenic switch". The authors confirmed their findings in vivo using B16 melanoma and LLC1 Lewis lung carcinoma inoculated in PPAR $\beta / \delta^{-/-}$mice, in which they observed dramatically reduced tumor angiogenesis and growth. PPAR $\beta / \delta$ expression levels in human cancer samples further correlated with advanced stages of tumor progression and metastasis $[95,96]$.

Recently, PPAR $\beta / \delta$ activators (L165041 and GW501516) were shown to induce interleukin 8 (Il-8) expression in endothelial cells by transcriptional and posttranscriptional mechanisms [97], and enhanced production of IL- 8 due to PPAR $\beta / \delta$ activation caused not only elevated tumor angiogenesis, but also metastasis formation in vivo [98].

Our group further confirmed the general tumor-angiogenesis and cancer growth promoting effect of PPAR $\beta / \delta$ [14]. Although we observed a decrease of LLC1 cancer cell proliferation in vitro upon treatment with GW0742, tumor growth and metastases formation in LLC1 cancer bearing animals was enhanced upon administration of the PPAR $\beta / \delta$ agonist. Tumor vascularization was strongly increased, which supports the hypothesis that enhancement of angiogenesis by PPAR $\beta / \delta$ dominates the eventually growth-inhibiting function on cancer cells. To further determine the functional relevance of PPAR $\beta / \delta$ for tumor vascularization and identify angiogenic signaling pathways, we made use of mice with conditional inducible vascular overexpression of PPAR $\beta / \delta$ subcutaneously implanted with LLC1 cells. Vessel-specific overexpression of PPAR $\beta / \delta$ was sufficient to increase cancer growth, progression and metastases formation. Tumor-sorted endothelial cells were submitted to RNA-sequencing; 283 genes were found to be differentially expressed and cluster analysis revealed mostly up-regulation of genes upon overexpression of PPAR $\beta / \delta$ in endothelial cells. This argues for an angiogenesis boosting effect of $\operatorname{PPAR} \beta / \delta$ rather than a repression of antiangiogenic molecules to enhance angiogenesis. We identified six potential target genes of PPAR $\beta / \delta$, all of them known to be involved in tumor angiogenesis, by combining the top ten network analysis with a search for PPAR responsive elements: Vegf receptors 1 (Flt1), 2 (Kdr) and 3 (Flt4), [99,100], and platelet-derived growth factor receptor beta (Pdgfr $\beta$ ) [101], platelet-derived growth factor subunit B (Pdgfb) [102] and the tyrosinkinase KIT c-kit [103,104]. Finally, we confirmed that PPAR $\beta / \delta$ directly transcriptional activates $\operatorname{Pdgfr} \beta, \operatorname{Pdgfb}$, and $c-K i t$. PPAR $\beta / \delta$ tumor-angiogenesis promoting effects are mediated via activation of the PDGF/PDGFR pathway, c-Kit and probably the VEGF/VEGFR pathway [14].

Despite their beneficial effects on vascular inflammation and atherosclerosis, the therapeutic use of $\operatorname{PPAR} \beta / \delta$ agonists could be critical in cancer patients and should therefore in general not be considered as a therapeutic option.

\section{PPAR $\beta / \delta$ and Cell Death}

The first study demonstrating an inhibitory function of PPAR $\beta / \delta$ in cancer cell death appeared in 1999. He and colleagues revealed that the adenomatous polyposis coli (APC) tumor suppressor represses PPAR $\beta / \delta$ expression through inhibition of $\beta$-catenin/Tcf- 4 regulated transcription (CRT). APC/ $\beta$-catenin mutations can therefore lead to increased PPAR $\beta / \delta$ activity. Nonsteroidal anti-inflammatory drugs (NSAIDs) Sulindac and Indomethacin promoted apoptosis of colorectal cancer cells, which could be inhibited by overexpression of PPAR $\beta / \delta$. The authors demonstrated that NSAIDs suppressed activity 
of PPAR $\beta / \delta$ through the direct inhibition of DNA binding activity. As fatty acids and eicosanoids are ligands and modifiers of PPAR activity, NSAID-dependent changes in eicosanoid metabolism could also contribute to inhibition of PPAR $\beta / \delta$ activity. NSAIDs were therefore considered as an important therapeutic approach in colorectal carcinoma as they inhibited apoptosis-preventing PPAR $\beta / \delta$ activity also in the context of frequently occurring APC/ $\beta$-catenin mutations [105]. Other groups demonstrated that cyclooxygenase-derived prostaglandin E2 (PGE2) inhibits colon cancer cell apoptosis through the indirect transactivation of PPAR $\beta / \delta$. Of note, the authors showed that PGE2 specifically regulates PPAR $\beta / \delta$, not the other PPARs. The apoptosis inhibiting effects of PGE2 are mediated through indirect mediation of PPAR $\beta / \delta$ by activation of the PI3K/Akt signaling pathway [106]. Gupta et al. confirmed the antiapoptotic effect of PPAR $\beta / \delta$ activation in wildtype and PPAR $\beta / \delta$-deficient HCT116 colon carcinoma cells. Pretreatment of wildtype HCT116 cells with GW501516 reduced serum withdrawal induced apoptosis, which was not the case in PPAR $\beta / \delta$-deficient HCT116 cells, suggesting a specific effect of PPAR $\beta / \delta$ activation [7]. Nonsteroidal anti-inflammatory drugs (NSAIDs) were also shown to induce colorectal cancer cell apoptosis through other PPAR $\beta / \delta$ mediated mechanisms. NSAIDs

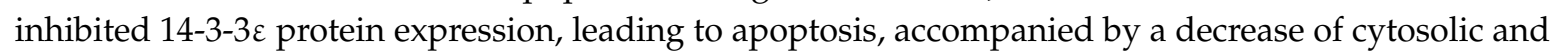
an increase of mitochondrial Bad [107]. The authors had already shown that PPAR $\beta / \delta$ transcriptionally activates $14-3-3 \varepsilon$ [70], and further confirmed their hypothesis in this study by overexpression of PPAR $\beta / \delta$, which rescued colorectal cancer cells from NSAID induced apoptosis and upregulated $14-3-3 \varepsilon$ protein levels. This additionally implicates the PPAR $\beta / \delta 14-3-3 \varepsilon$ pathway in colon cancer cell survival [107]. Again, in the setting of colorectal cancer, it has been shown that PPAR $\beta / \delta$ overexpression or activation antagonizes PPAR $\gamma$-induced apoptosis of cancer cells. PPAR $\gamma$ agonists induce apoptosis in these cancer cells through reduction of survivin, which in turn leads to apoptosis through increased caspase- 3 activity. PPAR $\beta / \delta$ agonists inhibit induction of this apoptotic pathway by increasing survivin expression levels [108]. The apoptosis inducing effects of NSAIDs in colon cancer were also linked to 15-lipoxygenase-1 (15-LOX-1) upregulation. 13-S-hydroxyoctadecadienoic acid (13-S-HODE), the primary product of 15-LOX-1 metabolism of linoleic acid, was found to decrease activity and downregulate expression of PPAR $\beta / \delta$ in colon cancer cells, thereby inducing apoptosis [109]. An interesting study of Cutler and colleagues showed that fibroblasts isolated from the mucosa of hereditary non polyposis colorectal cancer (HNPCC) patients produced 50-fold more PGE2 than normal fibroblasts [110]. PGE2 inhibits apoptosis of colonic carcinoma cells through the activation of PPAR $\beta / \delta$ [106]. As HNPCC patients are more susceptible to develop colorectal cancer (CRC), the authors hypothesized that the overproduction of PGI2 from the stroma of HNPCC patients prevents apoptosis of neoplastic lesions through activation of PPAR $\beta / \delta$ and therefore facilitates progression into a malignant state of CRC [110]. In contrast to all these studies, indicating an antiapoptotic function of PPAR $\beta / \delta$ in colon cancer cells, one report suggested a proapoptotic function of PPAR $\beta / \delta$ in the setting of colon carcinoma. In a model of chemically induced colon carcinogenesis using wildtype and PPAR $\beta / \delta$ knockout mice, treatment of mice with the agonist GW0742 resulted in higher colonic cell apoptosis in wildtype animals as assessed by TUNEL staining and subsequent quantification of cell counts from colon sections, which does not really assure cancer cell specificity. No changes in apoptotic cell counts were observed in colons from PPAR $\beta / \delta$ knockout mice upon agonistic activation of PPAR $\beta / \delta$ [23].

Maggiora et al. investigated the effects of linoleic (LA) and conjugated-linoleic acids (CLA) on the growth of several human tumor cell lines, comprising prostate, bladder, liver, glioblastoma and breast cancer cells. In contrast to Las, CLAs had a strong growth inhibitory effect in the cancer cell lines tested and were able to induce apoptosis in the more deviated cells. PPAR $\beta / \delta$ levels decreased strongly in apoptotic cancer cells upon CLA treatment, but not in cell lines where only an inhibition of cell proliferation without subsequent cell death could be observed [111].

Our group investigated the effects of PPAR $\beta / \delta$ activation on human and mouse melanoma cells. Although we could observe a reduction of melanoma cell proliferation upon PPAR $\beta / \delta$ activation 
either with GW0742 or with GW501516 at nanomolar concentrations, we did not observe changes in melanoma cell apoptosis [32].

In one lung cancer cell line, PPAR $\beta / \delta$ activation with the agonist L165041 or treatment with the NSAID Indomethacin alone had no effect on apoptosis, however, a combination of these molecules induced apoptosis in this cancer cell line [112]. In contrast, activation of PPAR $\beta / \delta$ with the more specific agonist GW501516 has been demonstrated to inhibit cisplatin-induced apoptosis in different lung cancer cell lines [62]. In line with this latter finding, Genini et al. reported enhanced apoptosis in different human non-small cell lung cancer (NSCLC) lines upon knockdown of PPAR $\beta / \delta$ [43]. We investigated the effects of PPAR $\beta / \delta$ activation or antagonism on mouse Lewis lung carcinoma cells and observed no differences in apoptosis for neither modulation of PPAR $\beta / \delta$ activity [14].

In contrast to the studies mentioned above, which mostly describe an antiapoptotic function of PPAR $\beta / \delta$ in cancer cells, Foreman and colleagues postulated a proapoptotic action of PPAR $\beta / \delta$ in a mouse mammary gland cell line. Treatment with very high concentrations of the PPAR $\beta / \delta$ agonist

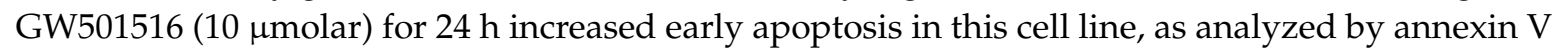
staining. However, prolonged treatment for $48 \mathrm{~h}$ at the same concentrations had no effect on apoptosis, which could raise some doubts concerning the conclusions given in this study [113]. A study from the same group could neither confirm the observation that NSAIDs decrease PPAR activation and expression in colon cancer cells, nor that PPAR $\beta / \delta$ exerts an antiapoptotic function in the setting of colon cancer. Using different human colon cancer cell lines treated with hydrogen peroxide to induce apoptosis and NSAIDs and different concentrations of the PPAR $\beta / \delta$ agonist GW0742, the authors did not observe a decrease of early (evidenced by annexin V labeling) or late (analyzed by PARP cleavage) apoptosis upon PPAR $\beta / \delta$ activation [51]. Bell and colleagues demonstrated that inhibition of PPAR $\beta / \delta$ using siRNA mediated knockdown or the antagonist GSK0660 sensitized neuroblastoma cells to all-trans retinoic acid induced cell death [114]. In line with this proapoptotic function of PPAR $\beta / \delta$, Péchery and colleagues reported enhanced apoptosis in tumor cells derived from high-grade bladder tumor upon activation with the PPAR $\beta / \delta$ agonist GW501516 [115]. Using only one prostate cancer cell line it has been postulated that the inhibition of PPAR $\beta / \delta$ with the antagonist GSK0660 partially inhibited ginsenoside $\mathrm{Rh} 2$ induced apoptosis [116]. In line with this study, another group recently reported a proapoptotic role of PPAR $\beta / \delta$ in prostate cancer cells. Treatment of one prostate cancer cell line with Telmisartan, an angiotensin receptor blocker, induced apoptosis, which could be partially inhibited by pharmacological or genetic down-regulation of PPAR $\beta / \delta$ activity or expression [117]. Additionally, in a nasopharyngeal carcinoma cell line, proapoptotic functions of PPAR $\beta / \delta$ could be demonstrated. Using in vitro and in vivo xenograft assays, high concentrations of GW501516 (10 or $30 \mu \mathrm{molar}$ ) induced apoptosis of the nasopharyngeal cancer cells. The authors proposed as underlying mechanisms the activation of adenosine monophosphate-activated protein kinase (AMPK $\alpha$ ) and downregulation of integrin-linked kinase (ILK), as the AMPK inhibitor compound $C$ was able to inhibit the reduction of ILK expression induced by GW501516 [118]. Employing the same cell line, the authors further implicated the microRNA miR-206 in the apoptosis promoting effects of PPAR $\beta / \delta$ activation, as they observed an induction of miR-206 upon GW501516 mediated PPAR $\beta / \delta$ activation, which could be antagonized by the PPAR $\beta / \delta$ antagonist GSK3787 or the AMPK antagonist dorsomorphin [119].

In conclusion, it is not perfectly clear if PPAR $\beta / \delta$ prevents or stimulates cancer cell death. Although the majority of studies suggest that PPAR $\beta / \delta$ has an antiapoptotic function in cancer cells, some reports evoke the contrary and others do not observe implication of PPAR $\beta / \delta$ in apoptotic cancer cell death at all. This might be due to cancer cell type specific differences, but also to discrepancies in experimental set ups.

\section{PPAR $\beta / \delta$ and Tumor Suppressors}

In addition to positive regulation of growth-promoting signals, cancer development also requires inhibition of negative growth regulators, i.e., escaping the action of tumor suppressor genes [12]. Although a large number of publications described the overall effects of PPAR $\beta / \delta$ modulation on tumor 
growth, knowledge on PPAR $\beta / \delta$ and tumor suppressor genes is relatively limited. Mice with mutations in the adenomatous polyposis coli (APC) tumor suppressor are frequently used as a tool for PPAR research in colon cancer, but also a direct function of the APC tumor suppressor on PPAR $\beta / \delta$ expression has been described. APC represses PPAR $\beta / \delta$ expression through inhibition of $\beta$-catenin/Tcf- 4 regulated transcription in colon cancer cells [105]. Besides colon cancer cells, inactivating mutations in APC or the Axin tumor suppressor proteins or activating mutations in $\beta$-catenin resulting in positive effects on T-cell factor (TCF)-regulated transcription have been described in several cancer types. Zhai et al. reported mutations leading to $\beta$-catenin deregulation in half of ovarian endometrioid adenocarcinomas. They found elevated expression of the MMP-7, CCND1 (Cyclin D1), CX43 (Connexin 43), ITF2 and also PPAR $\beta / \delta$ genes in ovarian endometrioid adenocarcinomas with deregulated $\beta$-catenin [120]. Transformation of intestinal epithelial cells with the K-Ras oncogene led to increased expression and activity of PPAR $\beta / \delta$. Mechanistically, PPAR $\beta / \delta$ up-regulation was due to increased mitogen-activated protein kinase activity; and PPAR $\beta / \delta$ activation required the endogenous production of prostacyclins via the cyclooxygenase-2 pathway [121]. An initial important report from mice with inactivation of the APC tumor suppressor showed that treatment with the PPAR $\beta / \delta$ agonist GW501516 resulted in a significant increase in the number and size of intestinal polyps [7]. In contrast to the reports mentioned above, another study confirmed APC/beta-catenin-dependent expression of Cyclin D1, while expression of PPAR $\beta / \delta$ was not different in colon or intestinal polyps from wild-type or Apc(min) heterozygous mice or in human colon cancer cell lines with mutations in APC or beta-catenin [122]. This study based exclusively on the use of a polyclonal antibody in Western blots. The quality of the available PPAR $\beta / \delta$ antibodies is still a matter of concern.

Regarding the Wilms' tumor suppressor WT1, we showed that PPAR $\beta / \delta$ activation in melanoma cells inhibits its expression via direct transcriptional repression [32]. WT1 was originally identified as a tumor suppressor based on its mutational inactivation in nephroblastoma [123,124], but later studies provided evidence that WT1 might act as an oncogene $[60,101,104,125,126]$. Wt1 was up-regulated instead of downregulated in endothelial cells with PPAR $\beta / \delta$ overexpression [14], which suggests cell-type dependent differential regulation of Wt 1 by PPAR $\beta / \delta$. Whether PPAR $\beta / \delta$ is a direct activator of WT1 in endothelial cells and other cell-types remains to be determined.

Epidermal growth factor receptor (EGFR) signaling promotes breast cancer cell proliferation and tumorigenesis. It has been shown that EGFR ligands signal through the ERK and the phophatidylinositol-3-kinase cascades, resulting in activation of the transcription factor NF-kappaB. The NF-kappaB transcription factor directly activates the promoter of fatty-acid binding protein 5 (FABP5) resulting in increased FABP5 protein expression, which in turn shuttles endogenous ligands to PPAR $\beta / \delta$ [53]. In contrast, Krüppel-like factor KLF2 inhibits FABP5 protein expression and subsequent $\operatorname{PPAR} \beta / \delta$ activation and thus, might act as a tumor suppressor in breast cancer cells [53].

Transducer of ErbB-2.1 (Tob1) is another tumor suppressor protein, which is inactivated in different cancer types including gastrointestinal cancers. Overexpression of Tob1 in gastric cancer cell lines induced the expression of Smad4 and p15. Tob1 decreased the phosphorylation of Akt and glycogen synthase kinase-3 $\beta$ (GSK3 $\beta$ ), resulting in reduced expression and the transcriptional activity of $\beta$-catenin, which in turn decreased the expression of PPAR $\beta / \delta$, cyclin D1, cyclin-dependent kinase- 4 (CDK4) and urokinase plasminogen activator receptor (uPAR) in gastric cancer cells [127]. These data are in agreement with the general regulation of PPAR $\beta / \delta$ by $\beta$-catenin and provide an additional complex signaling pathway for stimulation of PPAR $\beta / \delta$ activity in cancer progression.

In neuroblastoma cell lines, all-trans-retinoic acid reduced expression of the stem cell factor Sox2 in cell lines with low expression of the tumor suppressor p53, while this was not the case in cells with wild type p53. However, PPAR $\beta / \delta$ activation with GW0742 reduced SOX2 expression independent on the p53 status of the cells. The authors concluded that activating PPAR $\beta / \delta$ induces cell differentiation through p53- and SOX2-dependent signaling pathways in neuroblastoma cells and tumors [29]. However, the exact interaction between retinoic acid and PPAR $\beta / \delta$ signaling on SOX2 expression and the possible role of p53 therein remains to be determined. 
In smooth muscle cells, the PPAR $\beta / \delta$ agonist L-165041 inhibited dose-dependently proliferation by blocking $\mathrm{G}(1)$ to $S$ phase progression and repressing the phosphorylation of retinoblastoma protein $(\mathrm{Rb})$. In a carotid artery injury model in vivo, L-165041 inhibited neointima formation [128]. To our knowledge, this is the only report linking retinoblastoma protein and PPAR $\beta / \delta$ activation. Whether these findings are relevant for cancer cell proliferation or tumor angiogenesis remains to be determined.

\section{PPAR $\beta / \delta$ and Invasion and Metastasis}

Abdollahi et al. were the first to correlate PPAR $\beta / \delta$ expression levels with advanced pathological tumor stage and increased risk for distant metastasis. Statistical analyses of PPAR $\beta / \delta$ expression in published large-scale microarray data from cancer patients with prostate, breast, and endometrial adenocarcinoma revealed significantly increased PPAR $\beta / \delta$ expression levels in cases of higher malignant grade and distant metastasis formation [95]. Similar observations were made by Yoshinaga and colleagues who found an increased risk for colorectal cancer patients with high expression of PPAR $\beta / \delta$ and cyclooxygenase (COX)2 in the primary tumor to develop distant liver metastasis, consequently leading to a poor prognostic outcome [96]. In contrast to these studies, one group reported decreased invasion capacity of pancreatic cancer cells in vitro upon PPAR $\beta / \delta$ activation with GW501516 as well as downregulated prometastatic Matrix metalloproteinase-9 (MMP9) expression [129]. A similar study implying in vitro approaches using breast cancer cell lines demonstrated decreased migration and invasion upon PPAR $\beta / \delta$ activation with GW501516. PPAR $\beta / \delta$ mediated inhibition of breast cancer cell migration and invasion was proposed to be regulated via thrombospondin-1 (TSP-1) and its degrading protease, a disintegrin and metalloprotease domains with thrombospondin motifs 1 (ADAMTS1), as knockdown of ADAMTS1 reduced the effects of PPAR $\beta / \delta$ activation; and ADAMTS1 promoter activity was increased by GW501516 [130].

Interestingly, yeast-two hybrid screening identified the metastasis suppressor NDP Kinase alpha (NM23-H2) as a binding protein of PPAR $\beta / \delta$ [131]. NM23 genes have been shown to suppress metastasis development [132]. Overexpression of NM23-H2 in cholangiocarcinoma cells downregulated PPAR $\beta / \delta$ expression, impedes PPAR $\beta / \delta$ promoter activity and diminishes GW501516 induced cholangiocarcinoma cell proliferation. Reactivation of NM23-H2 was suggested as a therapeutic approach in cholangiocarcinoma metastasis [131].

Zuo and collaborators further demonstrated the importance of PPAR $\beta / \delta$ in metastatic cancer. Using an experimental mouse model of metastasis formation by tail vein injection of syngenic tumor cells (B16 melanoma and LLC1 Lewis lung carcinoma cells), the authors showed that PPAR $\beta / \delta$ knockdown in the respective cancer cells inhibited metastasis formation. Additionally, the potential of colon cancer cells (HCT116) to form metastasis in vivo was abolished completely upon genetic deletion of PPAR $\beta / \delta$. Treatment of mice with the PPAR $\beta / \delta$ agonist GW0742 enhanced metastasis formation. The metastatic potential of PPAR $\beta / \delta$ in cancer cells was confirmed in orthotopic tumor models, confirming that also spontaneous metastasis formation was dramatically reduced upon knockdown of PPAR $\beta / \delta$. Using heterozygous PPAR $\beta / \delta$ mice for syngenic tumor cell vein injection the authors further demonstrated that high expression of PPAR $\beta / \delta$ in cancer cells is the most important factor for metastasis formation as heterozygous PPAR $\beta / \delta$ mice developed fewer metastasis than their wildtype littermates, but exhibited the most important reduction of metastasis formation when injected with PPAR $\beta / \delta$ knockdown cancer cells. Transcriptome profiling of HCT116 wildtype and PPAR $\beta / \delta$ knockout cells identified gap junction protein alpha 1 (GJA1), vimentin (VIM), secreted protein acidic rich in cysteine (SPARC), neuregulin-1 (NRG1), CXCL8 (IL-8), stanniocalcin-1 (STC1), and synuclein gamma (breast cancer-specific protein 1 ; SNCG) as pro-metastatic PPAR $\beta / \delta$ targets. Finally, the authors further confirmed the correlation of high PPAR $\beta / \delta$ expression and significantly reduced metastasis-free survival in various cancer patient (colorectal, lung, breast) cohorts, including the largest reported cohort of 1609 breast cancer patients [98].

In profound contrast to the extensive in vivo study of Zuo, Lim and coworkers reported increased melanoma cell migration and invasion upon treatment with the PPAR $\beta / \delta$ antagonist $10 \mathrm{~h}$ as well 
as increased metastasis formation in PPAR $\beta / \delta$ knockout mice [133]. This antagonist had so far not been used in other studies and results were not confirmed employing well established antagonists as GSK0660 or GSK3787. Conversely, Ham and colleagues demonstrated that activation of PPAR $\beta / \delta$ in highly metastatic melanoma cell lines provoked an upregulation of Snail, a decrease of E-cadherin, and a stimulation of migration and invasion, which could be reversed by knockdown of PPAR $\beta / \delta$. $\operatorname{PPAR} \beta / \delta$ therefore seems to promote the high metastatic potential of aggressive melanoma [134].

Our group confirmed pro-metastatic effects of PPAR $\beta / \delta$ activation. Syngenic subcutaneous LLC1 tumor cell implantation resulted in significantly increased lung and liver metastasis when animals received the PPAR $\beta / \delta$ agonist GW0742. Interestingly, we also observed increased spontaneous metastatic spreading in a model with inducible conditional vascular-specific overexpression of PPAR $\beta / \delta$, indicating that the proangiogenic function of PPAR $\beta / \delta$ importantly contributes to metastatic tumor progression [14].

Recently, an elegant study demonstrated the implication of PPAR $\beta / \delta$ in the pro-metastatic effects of dietary fats in colorectal cancer. Activation of PPAR $\beta / \delta$ with GW501516 induces cancer stem-like cell (CSC) expansion and accelerates liver metastasis in vivo. Analysis of promoters of self-renewal regulatory factors such as Oct4, Nanog, Sox2, and KLF4 identified a PPAR responsive element in the Nanog promoter. Activation of PPAR $\beta / \delta$ with GW501516 increased whereas knockout of PPAR $\beta / \delta$ decreased Nanog expression. Colonic CSC expansion was shown to be induced by PPAR $\beta / \delta$ through direct induction of Nanog expression via binding to its promoter. Furthermore, knockdown of Nanog abolished PPAR $\beta / \delta$ stimulation of hepatic metastasis formation. Similar to the exposure to GW501516, a high fat diet induced expression of Nanog, accelerated tumor growth and liver metastasis formation and knockout of PPAR $\beta / \delta$ completely inhibited these effects. This identifies a novel PPAR $\beta / \delta$-mediated mechanism responsible for the contribution of dietary fat to colorectal cancer initiation and metastasis [135].

In conclusion, overwhelming evidence suggests that PPAR $\beta / \delta$ promotes metastasis.

\section{PPAR $\beta / \delta$ and Replicative Immortality}

Activation of PPAR $\beta / \delta$ with GW501516 was shown to inhibit angiotensin (Ang) II induced premature senescence of human vascular smooth muscle cells (hVSMCs). Ang II treatment of hVSMCs provoked an increase of senescence associated beta galactosidase activity (SA $\beta$-gal), which was inhibited by GW501515, an effect that could be reversed by hVSMCs knockdown. A significant reduction of SA $\beta$-gal activity was also observed upon pretreatment with $\mathrm{N}$-acetyl-l-cysteine (NAC), a thiol antioxidant, suggesting that reactive oxygen species (ROS) mediate Ang II-induced premature senescence of hVSMCs. Activation of hVSMCs significantly reduced ROS accumulation as well as DNA damage in $h V S M C$ s treated with Ang II. PPAR $\beta / \delta$ mediated transcriptional up-regulation of antioxidant genes (glutathione peroxidase (GPx)-1, manganese superoxide dismutase (Mn-SOD), heme oxygenase (HO)-1, and Thioredoxin (Trx)-1) had been identified as the major mechanism in the inhibition of premature senescence of hVSMCs [136]. In a following study, the authors identified upregulation of phosphatase and tensin homolog deleted on chromosome 10 (PTEN), leading to suppression of phosphatidylinositol 3-kinase (PI3K)/Akt pathway, by PPAR $\beta / \delta$ as a second mechanism of senescence inhibition in hVSMCs [137]. Increase of PTEN and suppression of PI3K/Akt by PPAR $\beta / \delta$ activation was also the main pathway identified for senescence inhibition of UV-induced keratinocytes by the agonist GW501516 [138]. In human coronary artery endothelial cells, inhibition of Ang II induced senescence by PPAR $\beta / \delta$ was found to be dependent of transcriptional activation of Sirtuin (SIRT) 1. Downregulation or inhibition of SIRT1 abolished the effects of PPAR $\beta / \delta$ on Ang II induced ROS production and premature senescence, and resveratrol, a SIRT1 activator, mimicked PPAR $\beta / \delta$ agonist effects [139]. PPAR $\beta / \delta$ activation has also been shown to prevent doxorubicin induced cardiomyocyte senescence. The PPAR $\beta / \delta$ agonist L165041 prevented telomeric repeat factor (TRF) 2 downregulation, partially rescued cell proliferation blockage, significantly attenuated cytoskeletal remodeling and the early loss of plasma membrane integrity and significantly reduced SA- $\beta$-gal activity. Senescence 
inhibition was in this case shown to be dependent of B-cell lymphoma 6 protein (Bcl6) as a potent inhibitor of senescence, rendering cells unresponsive to antiproliferative signals from the p19ARF-p53 pathway. L1650141 increased the expression of Bcl6, which upon ligand binding, was released from PPAR $\beta / \delta$ and repressed its target genes, involved in DNA damage sensing and proliferation of checkpoint control [140]. In this context, it might be interesting to mention that our group observed an increase of TRF2, a protein that has a key role in the protective activity of telomeres [141], in tumor sorted endothelial cells from mice with vascular specific overexpression of PPAR $\beta / \delta$ (Wagner et al., unpublished results).

In contrast to these studies reporting senescence inhibition upon PPAR $\beta / \delta$ activation, Zhu and coworkers observed stimulation of Harvey sarcoma ras virus gene (Hras)-induced senescence by $\operatorname{PPAR} \beta / \delta$. 7,12-dimethylbenz[a]anthracene (DMBA)-initiation led to a higher percentage of malignant squamous cell carcinomas and a lower percentage of benign papillomas in PPAR $\beta / \delta$ knockout compared to wildtype animals. In vitro, Hras expressing PPAR $\beta / \delta$ knockout keratinocytes displayed less senescence as investigated by SA $\beta$-gal staining. The authors identified as the molecular mechanisms of this senescence induction by PPAR $\beta / \delta$ a potentiation of the RAF/MEK/ERK pathway and an inhibition of the PI3K/AKT pathway [142]. In a very similar study appearing in the same year, the authors showed that increased endoplasmatic reticulum (ER) stress attenuated senescence in part by up-regulating phosphorylated protein kinase B (p-AKT) and decreasing phosphorylated extracellular signal-regulated kinase ( $\mathrm{p}$-ERK), which was repressed by PPAR $\beta / \delta$ [143].

Cellular senescence has been linked to the development of endothelial cell dysfunction in atherosclerosis. Especially oxidative stress induced by ROS from lipid loaded macrophage foam cells has been linked to premature senescence of the vasculature. Riahi and coworkers exposed endothelial cells to the secretome of such foam cells and observed an increase of endothelial SA $\beta$-gal activity, p16 and p21 expression as well as a decrease of phosphorylated retinoblastoma protein. They found that senescence was induced by 4-hydroxnonenal (4-HNE) through stimulation of pro-oxidant thioredoxin-interacting protein (TXNIP). The lipid peroxidation product 4-HNE activated PPAR $\beta / \delta$ promoter activity. The PPAR $\beta / \delta$ agonist GW501516 enhanced TXNIP expression, whereas the antagonist GSK0660 reduced TXNIP promoter activity and inhibited 4-HNE induced senescence [144].

In contrast to the prosenescent effects of PPAR $\beta / \delta$ in endothelial cells, Bernal and colleagues reported that PPAR $\beta / \delta$ maintains the proliferative undifferentiated phenotype of adult neuronal precursor cells, probably through activation of SOX2, one self-renewal regulatory factor [145]. This is in line with the findings from Wang and colleagues showing that colonic cancer stem cell expansion was induced by PPAR $\beta / \delta$ through direct transcriptional activation of Nanog [135].

It has been described that PPAR $\beta / \delta$ amplifies Wnt signaling activity through direct interaction with $\beta$-catenin and direct transcriptional activation of the Wnt coreceptor low-density lipoprotein receptor-related protein (LRP) 5 [146]. Senescence associated reprogramming has been shown to upregulate an adult tissue stem-cell signature in lymphoma cells, activate Wnt signaling and distinct stem-cell markers. Former senescent lymphoma cells had a higher in vivo tumor initiation potential than their non-senescent counterparts [147]. Given these highly interesting findings, it will be extremely exciting to further clarify the role of PPAR $\beta / \delta$ in cancer related senescence, replicative immortality and cancer stemness.

\section{PPAR $\beta / \delta$ and Metabolism}

It is well established that the high tumor cell growth rate due to proliferation is connected to profound metabolic changes [12]. As early as 1927, Otto Warburg described an anomaly in cancer cell metabolism compared to normal cells-cancer cells largely depend on aerobic glycolysis for energy production [148-150]. Cancer metabolism is not only linked to proliferation, but also to tumor angiogenesis as rapidly growing tumor cells will turn on the "angiogenic switch" for increased oxygen supply in the tissue. Lack of oxygen results in hypoxia in the tissue, which results in stabilization of hypoxia- induced factors (Hif) [151-153] and subsequent activation/inhibition of downstream target 
genes, e.g., VEGF [154], erythropoietin [155], WT1 [156], PPAR $\alpha$ [157], glucose transporters (Glut-1 and Glut-3) and many other target genes involved in cancer metabolism (for a recent review see [158]). In contrast to PPAR $\alpha$, PPAR $\beta / \delta$ seems not to be directly regulated by Hif- 1 ; but Hif- 1 expression is stimulated by calcineurin A [159] and PPAR $\beta / \delta$ activates calcineurin [85]. Consequently, we observed an increase in calcineurin and Hif- 1 expression in the hearts of mice treated with the PPAR $\beta / \delta$ agonists GW0742 and GW501516 [85]. Whether this signaling cascade is relevant for PPAR $\beta / \delta$-dependent cancer progression remains to be established. Hypoxic stress has been shown to induce transcriptional activation of PPAR $\beta / \delta$ in HCT116 colon cancer cells. PPAR $\beta / \delta$ associated with p300 upon hypoxic stress in these cells. The p300 and the PI3K/Akt pathways seem to play a role in the regulation of PPAR $\beta / \delta$ transactivation as PI3K inhibitors or siRNA knockdown of Akt suppressed the PPAR $\beta / \delta$ transactivation in response to hypoxia [160]. Interestingly, hypoxia-induced IL-8 and VEGF expression was significantly attenuated in PPAR $\beta / \delta$-deficient colon cancer cells linking expression of PPAR $\beta / \delta$ in cancer cells to tumor angiogenesis and immune response [160]. The in vivo relevance of these findings for tumor growth remains to be determined. In addition, prostacyclin synthase, which catalyzes the conversion of prostaglandin H2 (PGH2) to prostaglandin I2 (PGI2) is upregulated in fibroblasts and cancer cells in response to hypoxia. PGI2 in turn stimulates PPAR $\beta / \delta$ and subsequent VEGF expression [161], which provides an additional link between hypoxia, metabolism, PPAR $\beta / \delta$ in the tumor stroma and angiogenesis. PPAR $\beta / \delta$ also protects chronic lymphocytic leukemia and breast cancer cells from harsh environmental conditions, i.e., hypoxia and low glucose concentrations, which was related to increased antioxidant expression, substrate utilization and mitochondrial performance providing additional evidence for PPAR $\beta / \delta$ as a positive regulator of cancer growth $[28,35]$.

Long chain fatty acids (LCFA) represent energy sources, components of cell membranes and are further processed into signaling molecules. Dietary fatty acids are linked to cancer risk especially colon cancer. Saturated fatty acids were positively associated with colon cancer risk, while polyunsaturated fatty acids showed inverse associations [162]. Experimental studies, however suggested that saturated long chain fatty acids (SLCFA) inhibit while unsaturated long chain fatty acids (ULCFA) might increase proliferation of different cancer cell lines $[163,164]$. A recent report provided novel mechanistic insights into this problem linking long chain fatty acid metabolism and cancer [165]. Saturated fatty acids bind to fatty acid binding protein 5 (FABP5) and displace endogenous ligands and retinoic acid (RA) from this transport protein. Thus, these ligands are not delivered to PPAR $\beta / \delta$ and its transcriptional activity is reduced while RA is diverted to the retinoic acid receptor (RAR), which becomes activated. In contrast, binding of unsaturated long-chain fatty acids to FABP5 has similar consequences for the displacement of RA and its subsequent binding to RARs, but results in nuclear import of the ULCFA/FABP5 complex and subsequent activation of PPAR $\beta / \delta$, which in turn results in increased cancer cell proliferation [165]. Although these results identify a central role for FABP5 for cancer cell proliferation and might explain the differences observed regarding PPAR $\beta / \delta$ and cancer cell proliferation dependent on the presence/absence of FABP5 and amounts of RA and endogenous PPAR ligands, the situation for in vivo experimental and clinical studies might be even more complex due to the interplay of the different hallmark capabilities.

PPAR $\beta / \delta$ is, however, not only activated by fatty acids presented by FABP5 in tumorigenesis. In mammary epithelium, overexpression of PDK1 resulted in increased phosphorylation of Akt and GSK3 $\beta$ and augmented expression of PPAR $\beta / \delta$ protein. Treatment with GW501516 increased the number of mammary tumors and reduced survival, which was even more pronounced in animals with PDK1 overexpression. This dramatic effect correlated with an increase in a specific metabolic gene signature indicative of glycolysis and greater levels of fatty acid and phospholipid metabolites in PDK1 overexpressing mice treated with GW501516 compared to treated wild-type control mice [38]. As these metabolic changes are common also in human tumors [166] and enable high tumor cell proliferation [167], it is possible that this mechanism plays a common role in tumor types with PPAR $\beta / \delta$ overexpression. In addition, GW501516 increases expression of glucose transporter 1 (Glut-1) and solute carrier family 1 member 5 (SLC1A5), which results in an increased influx of glucose and 
glutamine in different cancer cell types and subsequently augments cancer cell proliferation [15]. Furthermore, animals with direct specific overexpression of PPAR $\beta / \delta$ in the mammary epithelium were prone to the development of mammary tumors [36]. Infiltrating mammary ductal carcinomas developed after a latency of 12 months; GW501516 reduced tumor latency to 5 months. Histologically, PPAR $\beta / \delta$ overexpression was confirmed in the mammary epithelium. In agreement with the study by Pollock et al. [38], increased Akt phosphorylation was detected, but also mTOR was activated. Inhibition of mTOR by everolimus reduced cell proliferation and the malignant phenotype indicating the importance of this signaling pathway for PPAR $\beta / \delta$-dependent mammary tumorigenesis. Microarray and metabolomic analyses revealed a marked increase in the levels of phosphatidylcholine metabolites, lysophosphatidylcholine, lysophosphatidic acid and arachidonic acid metabolites, which correspond to PPAR $\beta / \delta$-dependent gene regulation involved in prostaglandin biosynthesis. Lysophosphatidic acid stimulated mTOR activation through Akt, and phosphatidic acid directly mediates activation of mTOR [36]. These results provided robust evidence for PPAR $\beta / \delta$ induced metabolic changes resulting in mTOR activation in mammary tumorigenesis. Taken together, several metabolites increase PPAR $\beta / \delta$ activity and PPAR $\beta / \delta$ stimulation induces complex metabolic alterations, which are mostly protumorigenic.

\section{PPAR $\beta / \delta$ and Immune Function}

PPAR $\beta / \delta$ agonists have been reported to inhibit the tumor necrosis factor (TNF) $\alpha$ induced up-regulation of monocyte chemoattractant protein (MCP)-1 and vascular cell adhesion protein (VCAM)-1 in endothelial cells, to inhibit cytokine induced nuclear translocation of NF-kappaB and to reduce monocyte binding to activated vascular cells [74]. They modulate acute inflammation by targeting the neutrophil-endothelial cell interaction and reducing tumor necrosis factor alpha induced endothelial chemokine ligand (CXCL) 1 release and VCAM-1, E-selectin and ICAM-1 expression [77]. Another study described potent inhibitory effects of the PPAR $\beta / \delta$ agonist GW0742 on lipopolysaccharide target genes as cyclooxygenase (COX)-2 and inducible nitric oxide synthase (iNOS) in macrophages. Lipopolysaccharide (LPS) is the most abundant component within the cell wall of Gram-negative bacteria. It can stimulate the release of inflammatory cytokines in various cell types, leading to an acute inflammatory response towards pathogens. It has been suggested that PPAR $\beta / \delta$ functions in modulating the program of macrophages during inflammatory responses [168]. PPAR $\beta / \delta$ modulation has been proposed to attenuate inflammation in atherosclerosis. A comparison between wildtype and PPAR $\beta / \delta$ knockout macrophages revealed that proinflammatory genes such as MMP9, IL- $1 \beta$ and MCP-1 were down-regulated in PPAR $\beta / \delta$ knockout macrophages. However, activation of PPAR $\beta / \delta$ with GW501516 suppressed the expression of MCP- 1 and IL- $1 \beta$, indicating that activation of PPAR $\beta / \delta$ is anti-inflammatory. As an explanation for this seemingly discrepancy of PPAR $\beta / \delta$ function in inflammation, a ligand-dependent interaction of PPAR $\beta / \delta$ with the anti-inflammatory transcriptional repressor BCL- 6 had been suggested. Without ligand, PPAR $\beta / \delta$ binds BCL- 6 . When activated with a PPAR $\beta / \delta$ ligand, BCL- 6 is released and suppresses proinflammatory pathways [75]. Monocytes can be differentiated in either a proinflammatory (M1 or classically activated macrophage, induced by TNF $\alpha$, bacterial LPS or interferon gamma) or an anti-inflammatory (M2 or alternatively activated macrophage, induced by interleukins). PPAR $\beta / \delta$ has an important role in the development of the M2 phenotype, as PPAR $\beta / \delta$ knockout cells were unable to acquire this alternatively activated macrophage phenotype upon interleukin-4 or-10 stimulation [169]. In contrast, Thulin and colleagues demonstrated that PPAR $\beta / \delta$ is regulated by the microRNA miR- 9 in monocytes and that activation of PPAR $\beta / \delta$ might be of importance in M1 proinflammatory, but not in M2 anti-inflammatory macrophages, as the PPAR $\beta / \delta$ agonist GW501516 induced expression of PPAR $\beta / \delta$ target genes in proinflammatory M1, but not in M2 macrophages [170]. Further studies confirmed the implication of PPAR $\beta / \delta$ in the modification of macrophage functions and the reprogramming of their activation status. Treatment of macrophages with modified low-density lipoproteins (LDLs) induced arginase I expression, which was abolished by the PPAR $\beta / \delta$ antagonist GW9662. In contrast, the PPAR $\beta / \delta$ agonist GW0742 strongly induced 
arginase I expression. PPAR $\beta / \delta$ activity in macrophages therefore impacts the balance of Th1/Th2 responses through specific induction of arginase I expression and activity [171]. Myelin-derived phosphatidylserine was found to mediate PPAR $\beta / \delta$ activation in macrophages after myelin uptake, a pathway leading to suppression of the production of inflammatory mediators, ameliorating experimental autoimmune encephalomyelitis (EAE), an animal model of multiple sclerosis [172]. Mukundan et al. identified PPAR $\beta / \delta$ as a transcriptional sensor of apoptotic cells in macrophages. Apoptotic cell feeding stimulated PPAR $\beta / \delta$ expression in macrophages, which then induced expression of opsonins, enhanced apoptotic cell clearance by macrophages and increased anti-inflammatory cytokine production [173]. As another mechanism of PPAR $\beta / \delta$ function in macrophages, induction of the immunoreceptor CD300a has been postulated. The PPAR $\beta / \delta$ agonist GW501516 activated CD300a expression in macrophages. Mice lacking CD300a showed chronic intestinal inflammation upon high fat diet and an increase in proinflammatory cytokines, specific for the M1 macrophage type. The PPAR $\beta / \delta / C D 300$ a pathway could therefore contribute to the anti-inflammatory action in macrophages [174]. Adhikary and colleagues investigated the global PPAR $\beta / \delta$-regulated signaling network in human monocyte-derived macrophages. They found a robust induction of PPAR $\beta / \delta$ expression upon monocyte to macrophage differentiation. Using PPAR $\beta / \delta$ agonists and inverse agonists, they identified two mechanisms by which PPAR $\beta / \delta$ regulates immune-modulatory genes: 1) canonical regulation through DNA binding at PPAR $\beta / \delta-R X R$ sites (PPREs), induced by agonists and repressed by inverse agonists, and 2) repression by agonists in the absence of PPAR $\beta / \delta$ DNA binding (inverse regulation). Inverse regulation concerned NF-kappaB and the signal transducer and activator of transcription (STAT) 1 target genes, resulting in the inhibition of multiple proinflammatory mediators consistent with anti-inflammatory effects of PPAR $\beta / \delta$ activation. Interestingly, they could also demonstrate specific immune stimulatory effects induced by PPAR $\beta / \delta$ agonists, a pro-survival effect on macrophages and inhibition of $\mathrm{CD} 32 \mathrm{~B}$ surface expression and stimulation of $\mathrm{T}$ cell activation. This confirms the strong anti-inflammatory function of PPAR $\beta / \delta$, but also indicates context-dependent specific immune-stimulatory actions of PPAR $\beta / \delta$ activation [175]. The same group aimed at elucidating the role of PPAR $\beta / \delta$ in the pro-tumorigenic polarization of tumor associated macrophages (TAMs) in ovarian cancer. In vitro, PPAR $\beta / \delta$ target genes such as pyruvate dehydrogenase kinase (PDK) 4 and angiopoietin-like protein (ANGPTL) 4 were robustly induced in monocyte derived macrophages, but the ligand response in TAMs was impaired and most PPAR $\beta / \delta$ target genes were refractory to synthetic agonists. Next, the authors compared freshly isolated ascites-associated TAMs from ovarian cancer patients with monocyte-derived macrophages from healthy donors. Many PPAR $\beta / \delta$ target genes as PDK4, ANGPTL4, and carnitine palmitoyl transferase (CPT) 1A were found to be up-regulated in TAMs and were refractory to stimulation with the PPAR $\beta / \delta$ agonist L-165041. The deregulation and unresponsiveness of target genes in TAMs was found to be due to the presence of endogenous activators in malignancy associated ascites, as ascites caused an equal deregulation in normal macrophages. Lipidomic analysis of ascites samples revealed high levels of polyunsaturated fatty acids (PUFA) [176], known as PPAR $\beta / \delta$ activators [177]. The deregulation of PPAR $\beta / \delta$ target genes by PUFA ligands stimulates the pro-tumorigenic conversion of host-derived monocytic cells and might contribute to tumor progression [176]. Very little is known about the PPAR $\beta / \delta$ function in other key immune cell types except macrophages. In 2008, protein expression of PPAR $\beta / \delta$ in activated human T-cells was described. It has been shown that PPAR $\beta / \delta$ is a transcriptional target of human type I interferon (IFN), stimulates T-cell proliferation and inhibits IFN induced apoptosis, which is partially mediated through enhanced extracellular signal-regulated kinases (ERK) 1/2 signaling [178]. More recently, it has been demonstrated that PPAR $\beta / \delta$ overexpression/activation in vivo inhibits thymic T-cell development by decreasing proliferation of $\mathrm{CD}^{-} \mathrm{CD}^{-}$double-negative stage 4 (DN4) thymocytes [179]. PPAR $\beta / \delta$ has further been reported to drive maturation of monocyte-derived dendritic cells towards an atypical phenotype with reduced stimulatory effects on T-cells [180]. An interesting in vivo study using murine models of septic shock induction confirmed general anti-inflammatory effects of PPAR $\beta / \delta$ activation. PPAR $\beta / \delta$ deletion had detrimental effects on cardiac and renal function, liver injury, lung 
inflammation and survival, which could not be attenuated by administration of the specific agonist PPAR $\beta / \delta$ GW0742. In wildtype animals, selective activation of PPAR $\beta / \delta$ attenuated the multiple organ injury and dysfunction and improved survival when administered acutely in rodent models of endotoxemia and polymicrobial sepsis. PPAR $\beta / \delta$ activation was proposed as an anti-inflammatory therapeutic approach for the treatment of conditions involving local and systemic inflammation [181]. Using an experimental model for multiple sclerosis, it has been shown that PPAR $\beta / \delta$ limits the expansion of pathogenic T helper cells and production of Interleukin 12 and Interferon gamma, thereby limiting autoinflammation in the central nervous system [182]. Similar, in acute cerulein and taurocholate induced pancreatitis mouse models, treatment with the PPAR $\beta / \delta$ agonist GW0742 reduced expression of proinflammatory enzymes and cytokines, neutrophil invasion and tissue and inflammatory deterioration in the pancreas [183]. In contrast, PPAR $\beta / \delta$ has been shown to be a negative regulator of mesenchymal stem cell (MSC) immunosuppressive function, as PPAR $\beta / \delta$ inhibition or genetic deletion enhanced the immunosuppressive properties of MSCs, involving an increased NF-kappaB, ICAM-1 and VCAM-1 activity [184]. Interestingly, also in natural killer (NK) cells, inhibition of PPAR $\beta / \delta$ was beneficial to restore cytotoxic anti-tumor activity. Obesity induced a PPAR driven lipid accumulation in NK cells causing inhibition of their cellular metabolism and inhibiting their function. PPAR $\beta / \delta$ agonists mimicked obesity effects and inhibited trafficking of the cytotoxic machinery to the NK cell-tumor junction, disenabling NK cells to reduce tumor growth in obesity in vivo. Inhibition of PPAR $\beta / \delta$ restored NK cell cytotoxicity [185]. Finally, it may be concluded that most studies identified PPAR $\beta / \delta$ function as anti-inflammatory, mainly in the setting of atherosclerosis. However, only few cancer related investigations exist. In this context, PPAR $\beta / \delta$ has pro-inflammatory and pro-tumorigenic functions by converting host monocytes in macrophages favoring tumor progression $[176,185]$ or impairing antitumor cytotoxicity of NK cells. Surely, more cancer related studies addressing the question how PPAR $\beta / \delta$ acts in different immune regulatory cells, tissues and conditions, are needed.

\section{Conclusions and Outlook}

PPAR $\beta / \delta$ functions have been studied extensively. We summarized here known PPAR $\beta / \delta$ effects on cell proliferation, induction of angiogenesis, cell death, function of tumor suppressors, replicative immortality and senescence, invasion and metastasis, tumor metabolism and immune function and mentioned underlying molecular mechanisms. Although not all cited manuscripts were directly related to cancer, one has to keep in mind that the different hallmark capabilities interplay during tumor progression $[12,13]$. Some controversies regarding the effects of PPAR $\beta / \delta$ activation for cancer progression still exist, which might relate to the different cellular or animal models used. The majority of reports, however, suggest that activation of PPAR $\beta / \delta$ might result in modifications of the hallmark capabilities in favor of a pro-tumorigenic profile. Thus, in contrast to the earlier notion of the therapeutic potential of PPAR $\beta / \delta$ agonists as "exercise mimetics" and potential treatments for metabolic syndrome [186-188], extreme caution should be applied when considering PPAR $\beta / \delta$ agonists for therapeutic purposes given their pro-tumorigenic properties.

For future approaches using PPAR $\beta / \delta$ modulation for potential cancer therapy, collaborations between different laboratories and pathologists are urgently needed to define exact expression patterns of PPAR $\beta / \delta$ in different types, stages and grades of cancer. Currently, already the antibody validation is a limiting factor. Reproducible immunostaining protocols established between different laboratories and precise annotation of cell types would be required to define, which patients might benefit from PPAR $\beta / \delta$ modulation according to expression pattern in cells of the different hallmark capabilities.

Author Contributions: Conceptualization, N.W. and K.-D.W.; writing-original draft preparation, N.W. and K.-D.W.; writing - review and editing, N.W. and K.-D.W.; funding acquisition, N.W. and K.-D.W. Both authors have read and agreed to the published version of the manuscript.

Funding: This research was funded by "Fondation ARC pour la recherche sur le cancer", grant number n_PJA 20161204650 (N.W.), Gemluc (N.W.), and Plan Cancer INSERM, Fondation pour la Recherche Médicale (K.-D.W.). 
Conflicts of Interest: The authors declare no conflict of interest.

\section{References}

1. Wagner, K.D.; Wagner, N. Peroxisome proliferator-activated receptor beta/delta (PPARbeta/delta) acts as regulator of metabolism linked to multiple cellular functions. Pharmacol. Ther. 2010, 125, 423-435. [CrossRef]

2. Lefebvre, P.; Chinetti, G.; Fruchart, J.C.; Staels, B. Sorting out the roles of PPAR alpha in energy metabolism and vascular homeostasis. J. Clin. Investig. 2006, 116, 571-580. [CrossRef]

3. Takada, I.; Makishima, M. Peroxisome proliferator-activated receptor agonists and antagonists: A patent review (2014-present). Expert Opin. Ther. Pat. 2020, 30, 1-13. [CrossRef] [PubMed]

4. Cheng, H.S.; Tan, W.R.; Low, Z.S.; Marvalim, C.; Lee, J.Y.H.; Tan, N.S. Exploration and Development of PPAR Modulators in Health and Disease: An Update of Clinical Evidence. Int. J. Mol. Sci. 2019, $20,5055$. [CrossRef] [PubMed]

5. Xi, Y.; Zhang, Y.; Zhu, S.; Luo, Y.; Xu, P.; Huang, Z. PPAR-Mediated Toxicology and Applied Pharmacology. Cells 2020, 9, 352. [CrossRef] [PubMed]

6. Müller, R. PPAR $\beta / \delta$ in human cancer. Biochimie 2017, 136, 90-99. [CrossRef]

7. Gupta, R.A.; Wang, D.; Katkuri, S.; Wang, H.; Dey, S.K.; DuBois, R.N. Activation of nuclear hormone receptor peroxisome proliferator-activated receptor-delta accelerates intestinal adenoma growth. Nat. Med. 2004, 10, 245-247. [CrossRef]

8. Harman, F.S.; Nicol, C.J.; Marin, H.E.; Ward, J.M.; Gonzalez, F.J.; Peters, J.M. Peroxisome proliferator-activated receptor-delta attenuates colon carcinogenesis. Nat. Med. 2004, 10, 481-483. [CrossRef]

9. Liu, Y.; Colby, J.K.; Zuo, X.; Jaoude, J.; Wei, D.; Shureiqi, I. The Role of PPAR- $\delta$ in Metabolism, Inflammation, and Cancer: Many Characters of a Critical Transcription Factor. Int. J. Mol. Sci. 2018, 19, 3339. [CrossRef]

10. Laganà, A.S.; Vitale, S.G.; Nigro, A.; Sofo, V.; Salmeri, F.M.; Rossetti, P.; Rapisarda, A.M.; La Vignera, S.; Condorelli, R.A.; Rizzo, G.; et al. Pleiotropic Actions of Peroxisome Proliferator-Activated Receptors (PPARs) in Dysregulated Metabolic Homeostasis, Inflammation and Cancer: Current Evidence and Future Perspectives. Int. J. Mol. Sci. 2016, 17, 999. [CrossRef]

11. Montagner, A.; Wahli, W.; Tan, N.S. Nuclear receptor peroxisome proliferator activated receptor (PPAR) $\beta / \delta$ in skin wound healing and cancer. Eur. J. Dermatol. 2015, 25 (Suppl. 1), 4-11. [CrossRef]

12. Hanahan, D.; Weinberg, R.A. Hallmarks of cancer: The next generation. Cell 2011, 144, 646-674. [CrossRef] [PubMed]

13. Hanahan, D.; Weinberg, R.A. The hallmarks of cancer. Cell 2000, 100, 57-70. [CrossRef]

14. Wagner, K.D.; Du, S.; Martin, L.; Leccia, N.; Michiels, J.F.; Wagner, N. Vascular PPAR $\beta / \delta$ Promotes Tumor Angiogenesis and Progression. Cells 2019, 8, 1623. [CrossRef] [PubMed]

15. Ding, J.; Gou, Q.; Jin, J.; Shi, J.; Liu, Q.; Hou, Y. Metformin inhibits PPAR $\delta$ agonist-mediated tumor growth by reducing Glut1 and SLC1A5 expressions of cancer cells. Eur. J. Pharmacol. 2019, 857, 172425. [CrossRef] [PubMed]

16. Wang, D.; Wang, H.; Guo, Y.; Ning, W.; Katkuri, S.; Wahli, W.; Desvergne, B.; Dey, S.K.; DuBois, R.N. Crosstalk between peroxisome proliferator-activated receptor delta and VEGF stimulates cancer progression. Proc. Natl. Acad. Sci. USA 2006, 103, 19069-19074. [CrossRef] [PubMed]

17. Liu, Y.; Deguchi, Y.; Tian, R.; Wei, D.; Wu, L.; Chen, W.; Xu, W.; Xu, M.; Liu, F.; Gao, S.; et al. Pleiotropic Effects of PPARD Accelerate Colorectal Tumorigenesis, Progression, and Invasion. Cancer Res. 2019, 79, 954-969. [CrossRef]

18. Zhou, D.; Jin, J.; Liu, Q.; Shi, J.; Hou, Y. PPAR $\delta$ agonist enhances colitis-associated colorectal cancer. Eur. J. Pharmacol. 2019, 842, 248-254. [CrossRef]

19. Mao, F.; Xu, M.; Zuo, X.; Yu, J.; Xu, W.; Moussalli, M.J.; Elias, E.; Li, H.S.; Watowich, S.S.; Shureiqi, I. 15-Lipoxygenase-1 suppression of colitis-associated colon cancer through inhibition of the IL-6/STAT3 signaling pathway. FASEB J. 2015, 29, 2359-2370. [CrossRef]

20. Zuo, X.; Xu, M.; Yu, J.; Wu, Y.; Moussalli, M.J.; Manyam, G.C.; Lee, S.I.; Liang, S.; Gagea, M.; Morris, J.S.; et al. Potentiation of colon cancer susceptibility in mice by colonic epithelial PPAR- $\delta / \beta$ overexpression. J. Natl. Cancer Inst. 2014, 106, dju052. [CrossRef] 
21. Beyaz, S.; Mana, M.D.; Roper, J.; Kedrin, D.; Saadatpour, A.; Hong, S.J.; Bauer-Rowe, K.E.; Xifaras, M.E.; Akkad, A.; Arias, E.; et al. High-fat diet enhances stemness and tumorigenicity of intestinal progenitors. Nature 2016, 531, 53-58. [CrossRef] [PubMed]

22. Zuo, X.; Peng, Z.; Moussalli, M.J.; Morris, J.S.; Broaddus, R.R.; Fischer, S.M.; Shureiqi, I. Targeted genetic disruption of peroxisome proliferator-activated receptor-delta and colonic tumorigenesis. J. Natl. Cancer Inst. 2009, 101, 762-767. [CrossRef] [PubMed]

23. Marin, H.E.; Peraza, M.A.; Billin, A.N.; Willson, T.M.; Ward, J.M.; Kennett, M.J.; Gonzalez, F.J.; Peters, J.M. Ligand activation of peroxisome proliferator-activated receptor beta inhibits colon carcinogenesis. Cancer Res. 2006, 66, 4394-4401. [CrossRef] [PubMed]

24. Yang, L.; Zhou, J.; Ma, Q.; Wang, C.; Chen, K.; Meng, W.; Yu, Y.; Zhou, Z.; Sun, X. Knockdown of PPAR $\delta$ gene promotes the growth of colon cancer and reduces the sensitivity to bevacizumab in nude mice model. PLOS ONE 2013, 8, e60715. [CrossRef] [PubMed]

25. Martín-Martín, N.; Zabala-Letona, A.; Fernández-Ruiz, S.; Arreal, L.; Camacho, L.; Castillo-Martin, M.; Cortazar, A.R.; Torrano, V.; Astobiza, I.; Zúñiga-García, P.; et al. PPAR Elicits Ligand-Independent Repression of Trefoil Factor Family to Limit Prostate Cancer Growth. Cancer Res. 2018, 78, 399-409. [CrossRef] [PubMed]

26. Her, N.G.; Jeong, S.I.; Cho, K.; Ha, T.K.; Han, J.; Ko, K.P.; Park, S.K.; Lee, J.H.; Lee, M.G.; Ryu, B.K.; et al. PPAR $\delta$ promotes oncogenic redirection of TGF- $\beta 1$ signaling through the activation of the ABCA1-Cav1 pathway. Cell Cycle 2013, 12, 1521-1535. [CrossRef] [PubMed]

27. Morgan, E.; Kannan-Thulasiraman, P.; Noy, N. Involvement of Fatty Acid Binding Protein 5 and PPAR $\beta / \delta$ in Prostate Cancer Cell Growth. PPAR Res. 2010, 2010. [CrossRef]

28. Li, Y.J.; Sun, L.; Shi, Y.; Wang, G.; Wang, X.; Dunn, S.E.; Iorio, C.; Screaton, R.A.; Spaner, D.E. PPAR-delta promotes survival of chronic lymphocytic leukemia cells in energetically unfavorable conditions. Leukemia 2017, 31, 1905-1914. [CrossRef]

29. Yao, P.L.; Chen, L.; Dobrzański, T.P.; Zhu, B.; Kang, B.H.; Müller, R.; Gonzalez, F.J.; Peters, J.M. Peroxisome proliferator-activated receptor- $\beta / \delta$ inhibits human neuroblastoma cell tumorigenesis by inducing $\mathrm{p} 53-$ and SOX2-mediated cell differentiation. Mol. Carcinog. 2017, 56, 1472-1483. [CrossRef]

30. Balandaram, G.; Kramer, L.R.; Kang, B.H.; Murray, I.A.; Perdew, G.H.; Gonzalez, F.J.; Peters, J.M. Ligand activation of peroxisome proliferator-activated receptor- $\beta / \delta$ suppresses liver tumorigenesis in hepatitis $B$ transgenic mice. Toxicology 2016, 363-364, 1-9. [CrossRef]

31. Xu, L.; Han, C.; Lim, K.; Wu, T. Cross-talk between peroxisome proliferator-activated receptor delta and cytosolic phospholipase A(2)alpha/cyclooxygenase-2/prostaglandin E(2) signaling pathways in human hepatocellular carcinoma cells. Cancer Res. 2006, 66, 11859-11868. [CrossRef] [PubMed]

32. Michiels, J.F.; Perrin, C.; Leccia, N.; Massi, D.; Grimaldi, P.; Wagner, N. PPARbeta activation inhibits melanoma cell proliferation involving repression of the Wilms' tumour suppressor WT1. Pflugers Arch. 2010, 459, 689-703. [CrossRef] [PubMed]

33. Girroir, E.E.; Hollingshead, H.E.; Billin, A.N.; Willson, T.M.; Robertson, G.P.; Sharma, A.K.; Amin, S.; Gonzalez, F.J.; Peters, J.M. Peroxisome proliferator-activated receptor-beta/delta (PPARbeta/delta) ligands inhibit growth of UACC903 and MCF7 human cancer cell lines. Toxicology 2008, 243, 236-243. [CrossRef] [PubMed]

34. Ham, S.A.; Kim, E.; Yoo, T.; Lee, W.J.; Youn, J.H.; Choi, M.J.; Han, S.G.; Lee, C.H.; Paek, K.S.; Hwang, J.S.; et al. Ligand-activated interaction of PPAR $\delta$ with c-Myc governs the tumorigenicity of breast cancer. Int. J. Cancer 2018, 143, 2985-2996. [CrossRef]

35. Wang, X.; Wang, G.; Shi, Y.; Sun, L.; Gorczynski, R.; Li, Y.J.; Xu, Z.; Spaner, D.E. PPAR-delta promotes survival of breast cancer cells in harsh metabolic conditions. Oncogenesis 2016, 5, e232. [CrossRef]

36. Yuan, H.; Lu, J.; Xiao, J.; Upadhyay, G.; Umans, R.; Kallakury, B.; Yin, Y.; Fant, M.E.; Kopelovich, L.; Glazer, R.I. PPAR $\delta$ induces estrogen receptor-positive mammary neoplasia through an inflammatory and metabolic phenotype linked to mTOR activation. Cancer Res. 2013, 73, 4349-4361. [CrossRef]

37. Ghosh, M.; Ai, Y.; Narko, K.; Wang, Z.; Peters, J.M.; Hla, T. PPARdelta is pro-tumorigenic in a mouse model of COX-2-induced mammary cancer. Prostaglandins Other Lipid Mediat 2009, 88, 97-100. [CrossRef]

38. Pollock, C.B.; Yin, Y.; Yuan, H.; Zeng, X.; King, S.; Li, X.; Kopelovich, L.; Albanese, C.; Glazer, R.I. PPAR $\delta$ activation acts cooperatively with 3-phosphoinositide-dependent protein kinase-1 to enhance mammary tumorigenesis. PLoS ONE 2011, 6, e16215. [CrossRef] 
39. Levi, L.; Lobo, G.; Doud, M.K.; Von Lintig, J.; Seachrist, D.; Tochtrop, G.P.; Noy, N. Genetic ablation of the fatty acid-binding protein FABP5 suppresses HER2-induced mammary tumorigenesis. Cancer Res. 2013, 73, 4770-4780. [CrossRef]

40. Yin, Y.; Russell, R.G.; Dettin, L.E.; Bai, R.; Wei, Z.L.; Kozikowski, A.P.; Kopelovich, L.; Kopleovich, L.; Glazer, R.I. Peroxisome proliferator-activated receptor delta and gamma agonists differentially alter tumor differentiation and progression during mammary carcinogenesis. Cancer Res. 2005, 65, 3950-3957. [CrossRef]

41. Yao, P.L.; Chen, L.P.; Dobrzański, T.P.; Phillips, D.A.; Zhu, B.; Kang, B.H.; Gonzalez, F.J.; Peters, J.M. Inhibition of testicular embryonal carcinoma cell tumorigenicity by peroxisome proliferator-activated receptor- $\beta / \delta$ and retinoic acid receptor-dependent mechanisms. Oncotarget 2015, 6, 36319-36337. [CrossRef] [PubMed]

42. Montagner, A.; Delgado, M.B.; Tallichet-Blanc, C.; Chan, J.S.; Sng, M.K.; Mottaz, H.; Degueurce, G.; Lippi, Y.; Moret, C.; Baruchet, M.; et al. Src is activated by the nuclear receptor peroxisome proliferator-activated receptor $\beta / \delta$ in ultraviolet radiation-induced skin cancer. EMBO Mol. Med. 2014, 6, 80-98. [CrossRef] [PubMed]

43. Genini, D.; Garcia-Escudero, R.; Carbone, G.M.; Catapano, C.V. Transcriptional and Non-Transcriptional Functions of PPAR $\beta / \delta$ in Non-Small Cell Lung Cancer. PLoS ONE 2012, 7, e46009. [CrossRef] [PubMed]

44. He, P.; Borland, M.G.; Zhu, B.; Sharma, A.K.; Amin, S.; El-Bayoumy, K.; Gonzalez, F.J.; Peters, J.M. Effect of ligand activation of peroxisome proliferator-activated receptor-beta/delta (PPARbeta/delta) in human lung cancer cell lines. Toxicology 2008, 254, 112-117. [CrossRef]

45. Müller-Brüsselbach, S.; Ebrahimsade, S.; Jäkel, J.; Eckhardt, J.; Rapp, U.R.; Peters, J.M.; Moll, R.; Müller, R. Growth of transgenic RAF-induced lung adenomas is increased in mice with a disrupted PPARbeta/delta gene. Int. J. Oncol. 2007, 31, 607-611.

46. Wagner, K.D.; Benchetrit, M.; Bianchini, L.; Michiels, J.F.; Wagner, N. Peroxisome proliferator-activated receptor $\beta / \delta(\operatorname{PPAR} \beta / \delta)$ is highly expressed in liposarcoma and promotes migration and proliferation. J. Pathol. 2011, 224, 575-588. [CrossRef]

47. Zeng, L.; Geng, Y.; Tretiakova, M.; Yu, X.; Sicinski, P.; Kroll, T.G. Peroxisome proliferator-activated receptor-delta induces cell proliferation by a cyclin E1-dependent mechanism and is up-regulated in thyroid tumors. Cancer Res. 2008, 68, 6578-6586. [CrossRef]

48. Daikoku, T.; Tranguch, S.; Chakrabarty, A.; Wang, D.; Khabele, D.; Orsulic, S.; Morrow, J.D.; Dubois, R.N.; Dey, S.K. Extracellular signal-regulated kinase is a target of cyclooxygenase-1-peroxisome proliferator-activated receptor-delta signaling in epithelial ovarian cancer. Cancer Res. 2007, 67, 5285-5292. [CrossRef]

49. Röhrl, C.; Kaindl, U.; Koneczny, I.; Hudec, X.; Baron, D.M.; König, J.S.; Marian, B. Peroxisome-proliferator-activated receptors $\gamma$ and $\beta / \delta$ mediate vascular endothelial growth factor production in colorectal tumor cells. J. Cancer Res. Clin. Oncol. 2011, 137, 29-39. [CrossRef]

50. Takayama, O.; Yamamoto, H.; Damdinsuren, B.; Sugita, Y.; Ngan, C.Y.; Xu, X.; Tsujino, T.; Takemasa, I.; Ikeda, M.; Sekimoto, M.; et al. Expression of PPARdelta in multistage carcinogenesis of the colorectum: Implications of malignant cancer morphology. Br. J. Cancer 2006, 95, 889-895. [CrossRef]

51. Foreman, J.E.; Chang, W.C.; Palkar, P.S.; Zhu, B.; Borland, M.G.; Williams, J.L.; Kramer, L.R.; Clapper, M.L.; Gonzalez, F.J.; Peters, J.M. Functional characterization of peroxisome proliferator-activated receptor- $\beta / \delta$ expression in colon cancer. Mol. Carcinog. 2011, 50, 884-900. [CrossRef]

52. Yoshinaga, M.; Taki, K.; Somada, S.; Sakiyama, Y.; Kubo, N.; Kaku, T.; Tsuruta, S.; Kusumoto, T.; Sakai, H.; Nakamura, K.; et al. The expression of both peroxisome proliferator-activated receptor delta and cyclooxygenase-2 in tissues is associated with poor prognosis in colorectal cancer patients. Dig. Dis. Sci. 2011, 56, 1194-1200. [CrossRef]

53. Kannan-Thulasiraman, P.; Seachrist, D.D.; Mahabeleshwar, G.H.; Jain, M.K.; Noy, N. Fatty acid-binding protein 5 and PPARbeta/delta are critical mediators of epidermal growth factor receptor-induced carcinoma cell growth. J. Biol. Chem. 2010, 285, 19106-19115. [CrossRef] [PubMed]

54. Yao, P.L.; Morales, J.L.; Zhu, B.; Kang, B.H.; Gonzalez, F.J.; Peters, J.M. Activation of peroxisome proliferator-activated receptor- $\beta / \delta$ (PPAR- $\beta / \delta)$ inhibits human breast cancer cell line tumorigenicity. Mol. Cancer Ther. 2014, 13, 1008-1017. [CrossRef] [PubMed]

55. Zhu, B.; Bai, R.; Kennett, M.J.; Kang, B.H.; Gonzalez, F.J.; Peters, J.M. Chemoprevention of chemically induced skin tumorigenesis by ligand activation of peroxisome proliferator-activated receptor-beta/delta and inhibition of cyclooxygenase 2. Mol. Cancer Ther. 2010, 9, 3267-3277. [CrossRef] [PubMed] 
56. Bility, M.T.; Zhu, B.; Kang, B.H.; Gonzalez, F.J.; Peters, J.M. Ligand activation of peroxisome proliferator-activated receptor-beta/delta and inhibition of cyclooxygenase-2 enhances inhibition of skin tumorigenesis. Toxicol. Sci. 2010, 113, 27-36. [CrossRef]

57. Hollingshead, H.E.; Borland, M.G.; Billin, A.N.; Willson, T.M.; Gonzalez, F.J.; Peters, J.M. Ligand activation of peroxisome proliferator-activated receptor-beta/delta (PPARbeta/delta) and inhibition of cyclooxygenase 2 (COX2) attenuate colon carcinogenesis through independent signaling mechanisms. Carcinogenesis 2008, 29, 169-176. [CrossRef]

58. Kim, D.J.; Prabhu, K.S.; Gonzalez, F.J.; Peters, J.M. Inhibition of chemically induced skin carcinogenesis by sulindac is independent of peroxisome proliferator-activated receptor-beta/delta (PPARbeta/delta). Carcinogenesis 2006, 27, 1105-1112. [CrossRef]

59. Wagner, N.; Panelos, J.; Massi, D.; Wagner, K.D. The Wilms' tumor suppressor WT1 is associated with melanoma proliferation. Pflugers Arch. 2008, 455, 839-847. [CrossRef]

60. Wagner, N.; Michiels, J.F.; Schedl, A.; Wagner, K.D. The Wilms' tumour suppressor WT1 is involved in endothelial cell proliferation and migration: Expression in tumour vessels in vivo. Oncogene 2008, 27, 3662-3672. [CrossRef]

61. Wagner, N.; Wagner, K.D.; Scholz, H.; Kirschner, K.M.; Schedl, A. Intermediate filament protein nestin is expressed in developing kidney and heart and might be regulated by the Wilms' tumor suppressor Wt1. Am. J. Physiol. Regul. Integr. Comp. Physiol. 2006, 291, R779-R787. [CrossRef] [PubMed]

62. Pedchenko, T.V.; Gonzalez, A.L.; Wang, D.; DuBois, R.N.; Massion, P.P. Peroxisome proliferator-activated receptor beta/delta expression and activation in lung cancer. Am. J. Respir Cell Mol. Biol. 2008, 39, 689-696. [CrossRef] [PubMed]

63. Bishop-Bailey, D. PPARs and angiogenesis. Biochem. Soc. Trans. 2011, 39, 1601-1605. [CrossRef] [PubMed]

64. Xin, X.; Yang, S.; Kowalski, J.; Gerritsen, M.E. Peroxisome proliferator-activated receptor gamma ligands are potent inhibitors of angiogenesis in vitro and in vivo. J. Biol. Chem. 1999, 274, 9116-9121. [CrossRef]

65. Bishop-Bailey, D.; Hla, T. Endothelial cell apoptosis induced by the peroxisome proliferator-activated receptor (PPAR) ligand 15-deoxy-Delta12, 14-prostaglandin J2. J. Biol. Chem. 1999, 274, 17042-17048. [CrossRef]

66. Bishop-Bailey, D. Peroxisome proliferator-activated receptors in the cardiovascular system. Br. J. Pharmacol. 2000, 129, 823-834. [CrossRef]

67. Berger, J.; Leibowitz, M.D.; Doebber, T.W.; Elbrecht, A.; Zhang, B.; Zhou, G.; Biswas, C.; Cullinan, C.A.; Hayes, N.S.; Li, Y.; et al. Novel peroxisome proliferator-activated receptor (PPAR) gamma and PPARdelta ligands produce distinct biological effects. J. Biol. Chem. 1999, 274, 6718-6725. [CrossRef]

68. Sznaidman, M.L.; Haffner, C.D.; Maloney, P.R.; Fivush, A.; Chao, E.; Goreham, D.; Sierra, M.L.; LeGrumelec, C.; Xu, H.E.; Montana, V.G.; et al. Novel selective small molecule agonists for peroxisome proliferator-activated receptor delta (PPARdelta)-synthesis and biological activity. Bioorg. Med. Chem. Lett. 2003, 13, 1517-1521. [CrossRef]

69. Hatae, T.; Wada, M.; Yokoyama, C.; Shimonishi, M.; Tanabe, T. Prostacyclin-dependent apoptosis mediated by PPAR delta. J. Biol. Chem. 2001, 276, 46260-46267. [CrossRef]

70. Liou, J.Y.; Lee, S.; Ghelani, D.; Matijevic-Aleksic, N.; Wu, K.K. Protection of endothelial survival by peroxisome proliferator-activated receptor-delta mediated 14-3-3 upregulation. Arterioscler. Thromb. Vasc. Biol. 2006, 26, 1481-1487. [CrossRef]

71. Brunelli, L.; Cieslik, K.A.; Alcorn, J.L.; Vatta, M.; Baldini, A. Peroxisome proliferator-activated receptor-delta upregulates 14-3-3 epsilon in human endothelial cells via CCAAT/enhancer binding protein-beta. Circ. Res. 2007, 100, e59-e71. [CrossRef] [PubMed]

72. Liou, J.Y.; Wu, C.C.; Chen, B.R.; Yen, L.B.; Wu, K.K. Nonsteroidal anti-inflammatory drugs induced endothelial apoptosis by perturbing peroxisome proliferator-activated receptor-delta transcriptional pathway. Mol. Pharmacol. 2008, 74, 1399-1406. [CrossRef] [PubMed]

73. Bishop-Bailey, D. Peroxisome proliferator-activated receptor beta/delta goes vascular. Circ. Res. 2008, 102, 146-147. [CrossRef] [PubMed]

74. Rival, Y.; Benéteau, N.; Taillandier, T.; Pezet, M.; Dupont-Passelaigue, E.; Patoiseau, J.F.; Junquéro, D.; Colpaert, F.C.; Delhon, A. PPARalpha and PPARdelta activators inhibit cytokine-induced nuclear translocation of NF-kappaB and expression of VCAM-1 in EAhy926 endothelial cells. Eur. J. Pharmacol. 2002, 435, $143-151$. [CrossRef] 
75. Lee, C.H.; Chawla, A.; Urbiztondo, N.; Liao, D.; Boisvert, W.A.; Evans, R.M.; Curtiss, L.K. Transcriptional repression of atherogenic inflammation: Modulation by PPARdelta. Science 2003, 302, 453-457. [CrossRef]

76. Fan, Y.; Wang, Y.; Tang, Z.; Zhang, H.; Qin, X.; Zhu, Y.; Guan, Y.; Wang, X.; Staels, B.; Chien, S.; et al. Suppression of pro-inflammatory adhesion molecules by PPAR-delta in human vascular endothelial cells. Arterioscler. Thromb. Vasc. Biol. 2008, 28, 315-321. [CrossRef]

77. Piqueras, L.; Sanz, M.J.; Perretti, M.; Morcillo, E.; Norling, L.; Mitchell, J.A.; Li, Y.; Bishop-Bailey, D. Activation of PPARbeta/delta inhibits leukocyte recruitment, cell adhesion molecule expression, and chemokine release. J. Leukoc. Biol. 2009, 86, 115-122. [CrossRef]

78. Kim, H.J.; Ham, S.A.; Kim, S.U.; Hwang, J.Y.; Kim, J.H.; Chang, K.C.; Yabe-Nishimura, C.; Seo, H.G. Transforming growth factor-beta1 is a molecular target for the peroxisome proliferator-activated receptor delta. Circ. Res. 2008, 102, 193-200. [CrossRef]

79. D’Uscio, L.V.; Das, P.; Santhanam, A.V.; He, T.; Younkin, S.G.; Katusic, Z.S. Activation of PPAR $\delta$ prevents endothelial dysfunction induced by overexpression of amyloid- $\beta$ precursor protein. Cardiovasc. Res. 2012, 96, 504-512. [CrossRef]

80. Tian, X.Y.; Wong, W.T.; Wang, N.; Lu, Y.; Cheang, W.S.; Liu, J.; Liu, L.; Liu, Y.; Lee, S.S.; Chen, Z.Y.; et al. PPAR $\delta$ activation protects endothelial function in diabetic mice. Diabetes 2012, 61, 3285-3293. [CrossRef]

81. Quintela, A.M.; Jiménez, R.; Piqueras, L.; Gómez-Guzmán, M.; Haro, J.; Zarzuelo, M.J.; Cogolludo, A.; Sanz, M.J.; Toral, M.; Romero, M.; et al. PPAR $\beta$ activation restores the high glucose-induced impairment of insulin signalling in endothelial cells. Br. J. Pharmacol. 2014, 171, 3089-3102. [CrossRef] [PubMed]

82. Wawrzyniak, M.; Pich, C.; Gross, B.; Schütz, F.; Fleury, S.; Quemener, S.; Sgandurra, M.; Bouchaert, E.; Moret, C.; Mury, L.; et al. Endothelial, but not smooth muscle, peroxisome proliferator-activated receptor $\beta / \delta$ regulates vascular permeability and anaphylaxis. J. Allergy Clin. Immunol. 2015, 135, 1625-1635.e1625. [CrossRef] [PubMed]

83. Piqueras, L.; Reynolds, A.R.; Hodivala-Dilke, K.M.; Alfranca, A.; Redondo, J.M.; Hatae, T.; Tanabe, T.; Warner, T.D.; Bishop-Bailey, D. Activation of PPARbeta/delta induces endothelial cell proliferation and angiogenesis. Arterioscler. Thromb. Vasc. Biol. 2007, 27, 63-69. [CrossRef] [PubMed]

84. Gaudel, C.; Schwartz, C.; Giordano, C.; Abumrad, N.A.; Grimaldi, P.A. Pharmacological activation of PPARbeta promotes rapid and calcineurin-dependent fiber remodeling and angiogenesis in mouse skeletal muscle. Am. J. Physiol. Endocrinol. Metab. 2008, 295, E297-E304. [CrossRef] [PubMed]

85. Wagner, N.; Jehl-Piétri, C.; Lopez, P.; Murdaca, J.; Giordano, C.; Schwartz, C.; Gounon, P.; Hatem, S.N.; Grimaldi, P.; Wagner, K.D. Peroxisome proliferator-activated receptor beta stimulation induces rapid cardiac growth and angiogenesis via direct activation of calcineurin. Cardiovasc. Res. 2009, 83, 61-71. [CrossRef] [PubMed]

86. Wagner, K.D.; Vukolic, A.; Baudouy, D.; Michiels, J.F.; Wagner, N. Inducible Conditional Vascular-Specific Overexpression of Peroxisome Proliferator-Activated Receptor Beta/Delta Leads to Rapid Cardiac Hypertrophy. PPAR Res. 2016, 2016, 7631085. [CrossRef] [PubMed]

87. Park, J.R.; Ahn, J.H.; Jung, M.H.; Koh, J.S.; Park, Y.; Hwang, S.J.; Jeong, Y.H.; Kwak, C.H.; Lee, Y.S.; Seo, H.G.; et al. Effects of Peroxisome Proliferator-Activated Receptor- $\delta$ Agonist on Cardiac Healing after Myocardial Infarction. PLoS ONE 2016, 11, e0148510. [CrossRef]

88. Han, J.K.; Lee, H.S.; Yang, H.M.; Hur, J.; Jun, S.I.; Kim, J.Y.; Cho, C.H.; Koh, G.Y.; Peters, J.M.; Park, K.W.; et al. Peroxisome proliferator-activated receptor-delta agonist enhances vasculogenesis by regulating endothelial progenitor cells through genomic and nongenomic activations of the phosphatidylinositol 3-kinase/Akt pathway. Circulation 2008, 118, 1021-1033. [CrossRef]

89. Shearer, B.G.; Steger, D.J.; Way, J.M.; Stanley, T.B.; Lobe, D.C.; Grillot, D.A.; Iannone, M.A.; Lazar, M.A.; Willson, T.M.; Billin, A.N. Identification and characterization of a selective peroxisome proliferator-activated receptor beta/delta (NR1C2) antagonist. Mol. Endocrinol. 2008, 22, 523-529. [CrossRef]

90. Capozzi, M.E.; McCollum, G.W.; Savage, S.R.; Penn, J.S. Peroxisome proliferator-activated receptor- $\beta / \delta$ regulates angiogenic cell behaviors and oxygen-induced retinopathy. Invest. Ophthalmol. Vis. Sci. 2013, 54, 4197-4207. [CrossRef]

91. Müller-Brüsselbach, S.; Kömhoff, M.; Rieck, M.; Meissner, W.; Kaddatz, K.; Adamkiewicz, J.; Keil, B.; Klose, K.J.; Moll, R.; Burdick, A.D.; et al. Deregulation of tumor angiogenesis and blockade of tumor growth in PPARbeta-deficient mice. EMBO J. 2007, 26, 3686-3698. [CrossRef] [PubMed] 
92. Adamkiewicz, J.; Kaddatz, K.; Rieck, M.; Wilke, B.; Müller-Brüsselbach, S.; Müller, R. Proteomic profile of mouse fibroblasts with a targeted disruption of the peroxisome proliferator activated receptor-beta/delta gene. Proteomics 2007, 7, 1208-1216. [CrossRef] [PubMed]

93. Tung, J.J.; Hobert, O.; Berryman, M.; Kitajewski, J. Chloride intracellular channel 4 is involved in endothelial proliferation and morphogenesis in vitro. Angiogenesis 2009, 12, 209-220. [CrossRef] [PubMed]

94. Liu, T.; Bohlken, A.; Kuljaca, S.; Lee, M.; Nguyen, T.; Smith, S.; Cheung, B.; Norris, M.D.; Haber, M.; Holloway, A.J.; et al. The retinoid anticancer signal: Mechanisms of target gene regulation. Br. J. Cancer 2005, 93, 310-318. [CrossRef]

95. Abdollahi, A.; Schwager, C.; Kleeff, J.; Esposito, I.; Domhan, S.; Peschke, P.; Hauser, K.; Hahnfeldt, P.; Hlatky, L.; Debus, J.; et al. Transcriptional network governing the angiogenic switch in human pancreatic cancer. Proc. Natl. Acad. Sci. USA 2007, 104, 12890-12895. [CrossRef]

96. Yoshinaga, M.; Kitamura, Y.; Chaen, T.; Yamashita, S.; Tsuruta, S.; Hisano, T.; Ikeda, Y.; Sakai, H.; Nakamura, K.; Takayanagi, R.; et al. The simultaneous expression of peroxisome proliferator-activated receptor delta and cyclooxygenase-2 may enhance angiogenesis and tumor venous invasion in tissues of colorectal cancers. Dig. Dis. Sci. 2009, 54, 1108-1114. [CrossRef]

97. Meissner, M.; Hrgovic, I.; Doll, M.; Naidenow, J.; Reichenbach, G.; Hailemariam-Jahn, T.; Michailidou, D.; Gille, J.; Kaufmann, R. Peroxisome proliferator-activated receptor \{delta\} activators induce IL-8 expression in nonstimulated endothelial cells in a transcriptional and posttranscriptional manner. J. Biol. Chem. 2010, 285, 33797-33804. [CrossRef]

98. Zuo, X.; Xu, W.; Xu, M.; Tian, R.; Moussalli, M.J.; Mao, F.; Zheng, X.; Wang, J.; Morris, J.S.; Gagea, M.; et al. Metastasis regulation by PPARD expression in cancer cells. JCI Insight 2017, 2, e91419. [CrossRef]

99. Sadremomtaz, A.; Mansouri, K.; Alemzadeh, G.; Safa, M.; Rastaghi, A.E.; Asghari, S.M. Dual blockade of VEGFR1 and VEGFR2 by a novel peptide abrogates VEGF-driven angiogenesis, tumor growth, and metastasis through PI3K/AKT and MAPK/ERK1/2 pathway. Biochim. Biophys. Acta Gen. Subj. 2018, 1862, 2688-2700. [CrossRef]

100. Tammela, T.; Zarkada, G.; Wallgard, E.; Murtomäki, A.; Suchting, S.; Wirzenius, M.; Waltari, M.; Hellström, M.; Schomber, T.; Peltonen, R.; et al. Blocking VEGFR-3 suppresses angiogenic sprouting and vascular network formation. Nature 2008, 454, 656-660. [CrossRef]

101. El Maï, M.; Wagner, K.D.; Michiels, J.F.; Ambrosetti, D.; Borderie, A.; Destree, S.; Renault, V.; Djerbi, N.; Giraud-Panis, M.J.; Gilson, E.; et al. The Telomeric Protein TRF2 Regulates Angiogenesis by Binding and Activating the PDGFR $\beta$ Promoter. Cell Rep. 2014, 9, 1047-1060. [CrossRef] [PubMed]

102. Battegay, E.J.; Rupp, J.; Iruela-Arispe, L.; Sage, E.H.; Pech, M. PDGF-BB modulates endothelial proliferation and angiogenesis in vitro via PDGF beta-receptors. J. Cell Biol. 1994, 125, 917-928. [CrossRef] [PubMed]

103. Sihto, H.; Tynninen, O.; Bützow, R.; Saarialho-Kere, U.; Joensuu, H. Endothelial cell KIT expression in human tumours. J. Pathol. 2007, 211, 481-488. [CrossRef] [PubMed]

104. Wagner, K.D.; Cherfils-Vicini, J.; Hosen, N.; Hohenstein, P.; Gilson, E.; Hastie, N.D.; Michiels, J.F.; Wagner, N. The Wilms' tumour suppressor Wt1 is a major regulator of tumour angiogenesis and progression. Nat. Commun. 2014, 5, 5852. [CrossRef] [PubMed]

105. He, T.C.; Chan, T.A.; Vogelstein, B.; Kinzler, K.W. PPARdelta is an APC-regulated target of nonsteroidal anti-inflammatory drugs. Cell 1999, 99, 335-345. [CrossRef]

106. Wang, D.; Wang, H.; Shi, Q.; Katkuri, S.; Walhi, W.; Desvergne, B.; Das, S.K.; Dey, S.K.; DuBois, R.N. Prostaglandin E(2) promotes colorectal adenoma growth via transactivation of the nuclear peroxisome proliferator-activated receptor delta. Cancer Cell 2004, 6, 285-295. [CrossRef]

107. Liou, J.Y.; Ghelani, D.; Yeh, S.; Wu, K.K. Nonsteroidal anti-inflammatory drugs induce colorectal cancer cell apoptosis by suppressing 14-3-3epsilon. Cancer Res. 2007, 67, 3185-3191. [CrossRef]

108. Wang, D.; Ning, W.; Xie, D.; Guo, L.; DuBois, R.N. Peroxisome proliferator-activated receptor $\delta$ confers resistance to peroxisome proliferator-activated receptor $\gamma$-induced apoptosis in colorectal cancer cells. Oncogene 2012, 31, 1013-1023. [CrossRef]

109. Shureiqi, I.; Jiang, W.; Zuo, X.; Wu, Y.; Stimmel, J.B.; Leesnitzer, L.M.; Morris, J.S.; Fan, H.Z.; Fischer, S.M.; Lippman, S.M. The 15-lipoxygenase-1 product 13-S-hydroxyoctadecadienoic acid down-regulates PPAR-delta to induce apoptosis in colorectal cancer cells. Proc. Natl. Acad. Sci. USA 2003, 100, 9968-9973. [CrossRef] 
110. Cutler, N.S.; Graves-Deal, R.; LaFleur, B.J.; Gao, Z.; Boman, B.M.; Whitehead, R.H.; Terry, E.; Morrow, J.D.; Coffey, R.J. Stromal production of prostacyclin confers an antiapoptotic effect to colonic epithelial cells. Cancer Res. 2003, 63, 1748-1751.

111. Maggiora, M.; Bologna, M.; Cerù, M.P.; Possati, L.; Angelucci, A.; Cimini, A.; Miglietta, A.; Bozzo, F.; Margiotta, C.; Muzio, G.; et al. An overview of the effect of linoleic and conjugated-linoleic acids on the growth of several human tumor cell lines. Int. J. Cancer 2004, 112, 909-919. [CrossRef] [PubMed]

112. Fukumoto, K.; Yano, Y.; Virgona, N.; Hagiwara, H.; Sato, H.; Senba, H.; Suzuki, K.; Asano, R.; Yamada, K.; Yano, T. Peroxisome proliferator-activated receptor delta as a molecular target to regulate lung cancer cell growth. FEBS Lett. 2005, 579, 3829-3836. [CrossRef] [PubMed]

113. Foreman, J.E.; Sharma, A.K.; Amin, S.; Gonzalez, F.J.; Peters, J.M. Ligand activation of peroxisome proliferator-activated receptor-beta/delta (PPARbeta/delta) inhibits cell growth in a mouse mammary gland cancer cell line. Cancer Lett. 2010, 288, 219-225. [CrossRef] [PubMed]

114. Bell, E.; Ponthan, F.; Whitworth, C.; Westermann, F.; Thomas, H.; Redfern, C.P. Cell survival signalling through PPAR $\delta$ and arachidonic acid metabolites in neuroblastoma. PLoS ONE 2013, 8, e68859. [CrossRef] [PubMed]

115. Péchery, A.; Fauconnet, S.; Bittard, H.; Lascombe, I. Apoptotic effect of the selective PPAR $\beta / \delta$ agonist GW501516 in invasive bladder cancer cells. Tumour Biol. 2016, 37, 14789-14802. [CrossRef]

116. Tong-Lin Wu, T.; Tong, Y.C.; Chen, I.H.; Niu, H.S.; Li, Y.; Cheng, J.T. Induction of apoptosis in prostate cancer by ginsenoside Rh2. Oncotarget 2018, 9, 11109-11118. [CrossRef]

117. Wu, T.T.; Niu, H.S.; Chen, L.J.; Cheng, J.T.; Tong, Y.C. Increase of human prostate cancer cell (DU145) apoptosis by telmisartan through PPAR-delta pathway. Eur. J. Pharmacol. 2016, 775, 35-42. [CrossRef]

118. Ji, Y.; Li, H.; Wang, F.; Gu, L. PPAR $\beta / \delta$ Agonist GW501516 Inhibits Tumorigenicity of Undifferentiated Nasopharyngeal Carcinoma in C666-1 Cells by Promoting Apoptosis. Front. Pharmacol. 2018, 9, 648. [CrossRef]

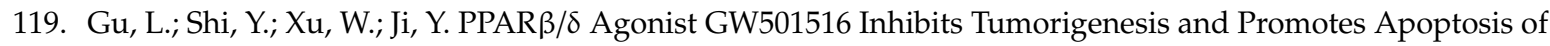
the Undifferentiated Nasopharyngeal Carcinoma C666-1 Cells by Regulating miR-206. Oncol. Res. 2019, 27, 923-933. [CrossRef]

120. Zhai, Y.; Wu, R.; Schwartz, D.R.; Darrah, D.; Reed, H.; Kolligs, F.T.; Nieman, M.T.; Fearon, E.R.; Cho, K.R. Role of beta-catenin/T-cell factor-regulated genes in ovarian endometrioid adenocarcinomas. Am. J. Pathol 2002, 160, 1229-1238. [CrossRef]

121. Shao, J.; Sheng, H.; DuBois, R.N. Peroxisome proliferator-activated receptors modulate K-Ras-mediated transformation of intestinal epithelial cells. Cancer Res. 2002, 62, 3282-3288. [PubMed]

122. Foreman, J.E.; Sorg, J.M.; McGinnis, K.S.; Rigas, B.; Williams, J.L.; Clapper, M.L.; Gonzalez, F.J.; Peters, J.M. Regulation of peroxisome proliferator-activated receptor-beta/delta by the APC/beta-CATENIN pathway and nonsteroidal antiinflammatory drugs. Mol. Carcinog 2009, 48, 942-952. [CrossRef] [PubMed]

123. Huff, V.; Miwa, H.; Haber, D.A.; Call, K.M.; Housman, D.; Strong, L.C.; Saunders, G.F. Evidence for WT1 as a Wilms tumor (WT) gene: Intragenic germinal deletion in bilateral WT. Am. J. Hum. Genet. 1991, 48, 997-1003. [PubMed]

124. Haber, D.A.; Buckler, A.J.; Glaser, T.; Call, K.M.; Pelletier, J.; Sohn, R.L.; Douglass, E.C.; Housman, D.E. An internal deletion within an 11p13 zinc finger gene contributes to the development of Wilms' tumor. Cell 1990, 61, 1257-1269. [CrossRef]

125. Wagner, K.D.; El Maï, M.; Ladomery, M.; Belali, T.; Leccia, N.; Michiels, J.F.; Wagner, N. Altered VEGF Splicing Isoform Balance in Tumor Endothelium Involves Activation of Splicing Factors Srpk1 and Srsf1 by the Wilms' Tumor Suppressor Wt1. Cells 2019, 8, 41. [CrossRef]

126. Sugiyama, H. WT1 (Wilms' tumor gene 1): Biology and cancer immunotherapy. Jpn. J. Clin. Oncol. 2010, 40, 377-387. [CrossRef]

127. Kundu, J.; Wahab, S.M.; Kundu, J.K.; Choi, Y.L.; Erkin, O.C.; Lee, H.S.; Park, S.G.; Shin, Y.K. Tob1 induces apoptosis and inhibits proliferation, migration and invasion of gastric cancer cells by activating Smad 4 and inhibiting $\beta$-catenin signaling. Int. J. Oncol. 2012, 41, 839-848. [CrossRef]

128. Lim, H.J.; Lee, S.; Park, J.H.; Lee, K.S.; Choi, H.E.; Chung, K.S.; Lee, H.H.; Park, H.Y. PPAR delta agonist L-165041 inhibits rat vascular smooth muscle cell proliferation and migration via inhibition of cell cycle. Atherosclerosis 2009, 202, 446-454. [CrossRef] 
129. Coleman, J.D.; Thompson, J.T.; Smith, R.W.; Prokopczyk, B.; Vanden Heuvel, J.P. Role of Peroxisome Proliferator-Activated Receptor $\beta / \delta$ and B-Cell Lymphoma- 6 in Regulation of Genes Involved in Metastasis and Migration in Pancreatic Cancer Cells. PPAR Res. 2013, 2013, 121956. [CrossRef]

130. Ham, S.A.; Yoo, T.; Lee, W.J.; Hwang, J.S.; Hur, J.; Paek, K.S.; Lim, D.S.; Han, S.G.; Lee, C.H.; Seo, H.G. ADAMTS1-mediated targeting of TSP-1 by PPAR $\delta$ suppresses migration and invasion of breast cancer cells. Oncotarget 2017, 8, 94091-94103. [CrossRef]

131. He, F.; York, J.P.; Burroughs, S.G.; Qin, L.; Xia, J.; Chen, D.; Quigley, E.M.; Webb, P.; LeSage, G.D.; Xia, X. Recruited metastasis suppressor NM23-H2 attenuates expression and activity of peroxisome proliferator-activated receptor $\delta$ (PPAR $\delta$ ) in human cholangiocarcinoma. Dig. Liver Dis. 2015, 47, 62-67. [CrossRef] [PubMed]

132. Steeg, P.S.; Palmieri, D.; Ouatas, T.; Salerno, M. Histidine kinases and histidine phosphorylated proteins in mammalian cell biology, signal transduction and cancer. Cancer Lett. 2003, 190, 1-12. [CrossRef]

133. Lim, J.C.W.; Kwan, Y.P.; Tan, M.S.; Teo, M.H.Y.; Chiba, S.; Wahli, W.; Wang, X. The Role of PPAR $\beta / \delta$ in Melanoma Metastasis. Int. J. Mol. Sci. 2018, 19, 2860. [CrossRef]

134. Ham, S.A.; Yoo, T.; Hwang, J.S.; Kang, E.S.; Lee, W.J.; Paek, K.S.; Park, C.; Kim, J.H.; Do, J.T.; Lim, D.S.; et al. Ligand-activated PPAR $\delta$ modulates the migration and invasion of melanoma cells by regulating Snail expression. Am. J. Cancer Res. 2014, 4, 674-682. [PubMed]

135. Wang, D.; Fu, L.; Wei, J.; Xiong, Y.; DuBois, R.N. PPARס Mediates the Effect of Dietary Fat in Promoting Colorectal Cancer Metastasis. Cancer Res. 2019, 79, 4480-4490. [CrossRef] [PubMed]

136. Kim, H.J.; Ham, S.A.; Paek, K.S.; Hwang, J.S.; Jung, S.Y.; Kim, M.Y.; Jin, H.; Kang, E.S.; Woo, I.S.; Lee, J.H.; et al. Transcriptional up-regulation of antioxidant genes by PPAR $\delta$ inhibits angiotensin II-induced premature senescence in vascular smooth muscle cells. Biochem. Biophys. Res. Commun. 2011, 406, 564-569. [CrossRef] [PubMed]

137. Kim, H.J.; Ham, S.A.; Kim, M.Y.; Hwang, J.S.; Lee, H.; Kang, E.S.; Yoo, T.; Woo, I.S.; Yabe-Nishimura, C.; Paek, K.S.; et al. PPAR $\delta$ coordinates angiotensin II-induced senescence in vascular smooth muscle cells through PTEN-mediated inhibition of superoxide generation. J. Biol. Chem. 2011, 286, 44585-44593. [CrossRef]

138. Ham, S.A.; Hwang, J.S.; Yoo, T.; Lee, H.; Kang, E.S.; Park, C.; Oh, J.W.; Lee, H.T.; Min, G.; Kim, J.H.; et al. Ligand-activated PPAR $\delta$ inhibits UVB-induced senescence of human keratinocytes via PTEN-mediated inhibition of superoxide production. Biochem. J. 2012, 444, 27-38. [CrossRef]

139. Kim, M.Y.; Kang, E.S.; Ham, S.A.; Hwang, J.S.; Yoo, T.S.; Lee, H.; Paek, K.S.; Park, C.; Lee, H.T.; Kim, J.H.; et al. The PPAR $\delta$-mediated inhibition of angiotensin II-induced premature senescence in human endothelial cells is SIRT1-dependent. Biochem. Pharmacol. 2012, 84, 1627-1634. [CrossRef]

140. Altieri, P.; Spallarossa, P.; Barisione, C.; Garibaldi, S.; Garuti, A.; Fabbi, P.; Ghigliotti, G.; Brunelli, C. Inhibition of doxorubicin-induced senescence by PPAR $\delta$ activation agonists in cardiac muscle cells: Cooperation between PPAR $\delta$ and Bcl6. PLoS ONE 2012, 7, e46126. [CrossRef]

141. Van Steensel, B.; Smogorzewska, A.; De Lange, T. TRF2 protects human telomeres from end-to-end fusions. Cell 1998, 92, 401-413. [CrossRef]

142. Zhu, B.; Ferry, C.H.; Blazanin, N.; Bility, M.T.; Khozoie, C.; Kang, B.H.; Glick, A.B.; Gonzalez, F.J.; Peters, J.M. PPAR $\beta / \delta$ promotes HRAS-induced senescence and tumor suppression by potentiating $\mathrm{p}$-ERK and repressing p-AKT signaling. Oncogene 2014, 33, 5348-5359. [CrossRef] [PubMed]

143. Zhu, B.; Ferry, C.H.; Markell, L.K.; Blazanin, N.; Glick, A.B.; Gonzalez, F.J.; Peters, J.M. The nuclear receptor peroxisome proliferator-activated receptor $-\beta / \delta(\operatorname{PPAR} \beta / \delta)$ promotes oncogene-induced cellular senescence through repression of endoplasmic reticulum stress. J. Biol. Chem. 2014, 289, 20102-20119. [CrossRef] [PubMed]

144. Riahi, Y.; Kaiser, N.; Cohen, G.; Abd-Elrahman, I.; Blum, G.; Shapira, O.M.; Koler, T.; Simionescu, M.; Sima, A.V.; Zarkovic, N.; et al. Foam cell-derived 4-hydroxynonenal induces endothelial cell senescence in a TXNIP-dependent manner. J. Cell Mol. Med. 2015, 19, 1887-1899. [CrossRef] [PubMed]

145. Bernal, C.; Araya, C.; Palma, V.; Bronfman, M. PPAR $\beta / \delta$ and PPAR $\gamma$ maintain undifferentiated phenotypes of mouse adult neural precursor cells from the subventricular zone. Front. Cell Neurosci. 2015, 9, 78. [CrossRef]

146. Scholtysek, C.; Katzenbeisser, J.; Fu, H.; Uderhardt, S.; Ipseiz, N.; Stoll, C.; Zaiss, M.M.; Stock, M.; Donhauser, L.; Böhm, C.; et al. PPAR $\beta / \delta$ governs Wnt signaling and bone turnover. Nat. Med. 2013, 19, 608-613. [CrossRef] 
147. Milanovic, M.; Fan, D.N.Y.; Belenki, D.; Däbritz, J.H.M.; Zhao, Z.; Yu, Y.; Dörr, J.R.; Dimitrova, L.; Lenze, D.; Monteiro Barbosa, I.A.; et al. Senescence-associated reprogramming promotes cancer stemness. Nature 2018, 553, 96-100. [CrossRef]

148. WARBURG, O. On respiratory impairment in cancer cells. Science 1956, 124, 269-270.

149. WARBURG, O. On the origin of cancer cells. Science 1956, 123, 309-314. [CrossRef]

150. Warburg, O.; Wind, F.; Negelein, E. THE METABOLISM OF TUMORS IN THE BODY. J. Gen. Physiol. 1927, 8, 519-530. [CrossRef]

151. Semenza, G.L. Expression of hypoxia-inducible factor 1: Mechanisms and consequences. Biochem. Pharmacol. 2000, 59, 47-53. [CrossRef]

152. Maxwell, P.H.; Dachs, G.U.; Gleadle, J.M.; Nicholls, L.G.; Harris, A.L.; Stratford, I.J.; Hankinson, O.; Pugh, C.W.; Ratcliffe, P.J. Hypoxia-inducible factor-1 modulates gene expression in solid tumors and influences both angiogenesis and tumor growth. Proc. Natl. Acad. Sci. USA 1997, 94, 8104-8109. [CrossRef] [PubMed]

153. Richard, D.E.; Berra, E.; Pouysségur, J. Angiogenesis: How a tumor adapts to hypoxia. Biochem. Biophys Res. Commun. 1999, 266, 718-722. [CrossRef]

154. Forsythe, J.A.; Jiang, B.H.; Iyer, N.V.; Agani, F.; Leung, S.W.; Koos, R.D.; Semenza, G.L. Activation of vascular endothelial growth factor gene transcription by hypoxia-inducible factor 1. Mol. Cell Biol. 1996, 16, 4604-4613. [CrossRef] [PubMed]

155. Wang, G.L.; Semenza, G.L. General involvement of hypoxia-inducible factor 1 in transcriptional response to hypoxia. Proc. Natl. Acad. Sci. USA 1993, 90, 4304-4308. [CrossRef] [PubMed]

156. Wagner, K.D.; Wagner, N.; Wellmann, S.; Schley, G.; Bondke, A.; Theres, H.; Scholz, H. Oxygen-regulated expression of the Wilms' tumor suppressor Wt1 involves hypoxia-inducible factor-1 (HIF-1). FASEB J. 2003, 17, 1364-1366. [CrossRef] [PubMed]

157. Narravula, S.; Colgan, S.P. Hypoxia-inducible factor 1-mediated inhibition of peroxisome proliferator-activated receptor alpha expression during hypoxia. J. Immunol 2001, 166, 7543-7548. [CrossRef]

158. Balamurugan, K. HIF-1 at the crossroads of hypoxia, inflammation, and cancer. Int. J. Cancer 2016, 138, 1058-1066. [CrossRef]

159. Liu, Y.V.; Hubbi, M.E.; Pan, F.; McDonald, K.R.; Mansharamani, M.; Cole, R.N.; Liu, J.O.; Semenza, G.L. Calcineurin promotes hypoxia-inducible factor 1alpha expression by dephosphorylating RACK1 and blocking RACK1 dimerization. J. Biol. Chem. 2007, 282, 37064-37073. [CrossRef]

160. Jeong, E.; Koo, J.E.; Yeon, S.H.; Kwak, M.K.; Hwang, D.H.; Lee, J.Y. PPAR $\delta$ deficiency disrupts hypoxia-mediated tumorigenic potential of colon cancer cells. Mol. Carcinog. 2014, 53, 926-937. [CrossRef]

161. Wang, J.; Ikeda, R.; Che, X.F.; Ooyama, A.; Yamamoto, M.; Furukawa, T.; Hasui, K.; Zheng, C.L.; Tajitsu, Y.; Oka, T.; et al. VEGF expression is augmented by hypoxia-induced PGIS in human fibroblasts. Int. J. Oncol. 2013, 43, 746-754. [CrossRef] [PubMed]

162. Hodge, A.M.; Williamson, E.J.; Bassett, J.K.; MacInnis, R.J.; Giles, G.G.; English, D.R. Dietary and biomarker estimates of fatty acids and risk of colorectal cancer. Int. J. Cancer 2015, 137, 1224-1234. [CrossRef] [PubMed]

163. Hardy, S.; Langelier, Y.; Prentki, M. Oleate activates phosphatidylinositol 3-kinase and promotes proliferation and reduces apoptosis of MDA-MB-231 breast cancer cells, whereas palmitate has opposite effects. Cancer Res. 2000, 60, 6353-6358. [PubMed]

164. Li, C.; Zhao, X.; Toline, E.C.; Siegal, G.P.; Evans, L.M.; Ibrahim-Hashim, A.; Desmond, R.A.; Hardy, R.W. Prevention of carcinogenesis and inhibition of breast cancer tumor burden by dietary stearate. Carcinogenesis 2011, 32, 1251-1258. [CrossRef]

165. Levi, L.; Wang, Z.; Doud, M.K.; Hazen, S.L.; Noy, N. Saturated fatty acids regulate retinoic acid signalling and suppress tumorigenesis by targeting fatty acid-binding protein 5. Nat. Commun. 2015, 6, 8794. [CrossRef]

166. Altenberg, B.; Greulich, K.O. Genes of glycolysis are ubiquitously overexpressed in 24 cancer classes. Genomics 2004, 84, 1014-1020. [CrossRef]

167. DeBerardinis, R.J.; Lum, J.J.; Hatzivassiliou, G.; Thompson, C.B. The biology of cancer: Metabolic reprogramming fuels cell growth and proliferation. Cell Metab. 2008, 7, 11-20. [CrossRef]

168. Welch, J.S.; Ricote, M.; Akiyama, T.E.; Gonzalez, F.J.; Glass, C.K. PPARgamma and PPARdelta negatively regulate specific subsets of lipopolysaccharide and IFN-gamma target genes in macrophages. Proc. Natl. Acad. Sci. USA 2003, 100, 6712-6717. [CrossRef] 
169. Kang, K.; Reilly, S.M.; Karabacak, V.; Gangl, M.R.; Fitzgerald, K.; Hatano, B.; Lee, C.H. Adipocyte-derived Th2 cytokines and myeloid PPARdelta regulate macrophage polarization and insulin sensitivity. Cell Metab. 2008, 7, 485-495. [CrossRef]

170. Thulin, P.; Wei, T.; Werngren, O.; Cheung, L.; Fisher, R.M.; Grandér, D.; Corcoran, M.; Ehrenborg, E. MicroRNA-9 regulates the expression of peroxisome proliferator-activated receptor $\delta$ in human monocytes during the inflammatory response. Int. J. Mol. Med. 2013, 31, 1003-1010. [CrossRef]

171. Gallardo-Soler, A.; Gómez-Nieto, C.; Campo, M.L.; Marathe, C.; Tontonoz, P.; Castrillo, A.; Corraliza, I. Arginase I induction by modified lipoproteins in macrophages: A peroxisome proliferator-activated receptor-gamma/delta-mediated effect that links lipid metabolism and immunity. Mol. Endocrinol. 2008, 22, 1394-1402. [CrossRef] [PubMed]

172. Bogie, J.F.; Jorissen, W.; Mailleux, J.; Nijland, P.G.; Zelcer, N.; Vanmierlo, T.; Van Horssen, J.; Stinissen, P.; Hellings, N.; Hendriks, J.J. Myelin alters the inflammatory phenotype of macrophages by activating PPARs. Acta Neuropathol. Commun. 2013, 1, 43. [CrossRef] [PubMed]

173. Mukundan, L.; Odegaard, J.I.; Morel, C.R.; Heredia, J.E.; Mwangi, J.W.; Ricardo-Gonzalez, R.R.; Goh, Y.P.; Eagle, A.R.; Dunn, S.E.; Awakuni, J.U.; et al. PPAR-delta senses and orchestrates clearance of apoptotic cells to promote tolerance. Nat. Med. 2009, 15, 1266-1272. [CrossRef]

174. Tanaka, T.; Tahara-Hanaoka, S.; Nabekura, T.; Ikeda, K.; Jiang, S.; Tsutsumi, S.; Inagaki, T.; Magoori, K.; Higurashi, T.; Takahashi, H.; et al. PPAR $\beta / \delta$ activation of CD300a controls intestinal immunity. Sci. Rep. 2014, 4, 5412. [CrossRef] [PubMed]

175. Adhikary, T.; Wortmann, A.; Schumann, T.; Finkernagel, F.; Lieber, S.; Roth, K.; Toth, P.M.; Diederich, W.E.; Nist, A.; Stiewe, T.; et al. The transcriptional PPAR $\beta / \delta$ network in human macrophages defines a unique agonist-induced activation state. Nucleic Acids Res. 2015, 43, 5033-5051. [CrossRef] [PubMed]

176. Schumann, T.; Adhikary, T.; Wortmann, A.; Finkernagel, F.; Lieber, S.; Schnitzer, E.; Legrand, N.; Schober, Y.; Nockher, W.A.; Toth, P.M.; et al. Deregulation of PPAR $\beta / \delta$ target genes in tumor-associated macrophages by fatty acid ligands in the ovarian cancer microenvironment. Oncotarget 2015, 6, 13416-13433. [CrossRef]

177. Xu, H.E.; Lambert, M.H.; Montana, V.G.; Parks, D.J.; Blanchard, S.G.; Brown, P.J.; Sternbach, D.D.; Lehmann, J.M.; Wisely, G.B.; Willson, T.M.; et al. Molecular recognition of fatty acids by peroxisome proliferator-activated receptors. Mol. Cell 1999, 3, 397-403. [CrossRef]

178. Al Yacoub, N.; Romanowska, M.; Krauss, S.; Schweiger, S.; Foerster, J. PPARdelta is a type 1 IFN target gene and inhibits apoptosis in T cells. J. Invest. Dermatol. 2008, 128, 1940-1949. [CrossRef]

179. Mothe-Satney, I.; Murdaca, J.; Sibille, B.; Rousseau, A.S.; Squillace, R.; Le Menn, G.; Rekima, A.; Larbret, F.; Pelé, J.; Verhasselt, V.; et al. A role for Peroxisome Proliferator-Activated Receptor Beta in T cell development. Sci. Rep. 2016, 6, 34317. [CrossRef]

180. Jakobsen, M.A.; Petersen, R.K.; Kristiansen, K.; Lange, M.; Lillevang, S.T. Peroxisome proliferator-activated receptor alpha, delta, gamma1 and gamma2 expressions are present in human monocyte-derived dendritic cells and modulate dendritic cell maturation by addition of subtype-specific ligands. Scand. J. Immunol. 2006, 63, 330-337. [CrossRef]

181. Kapoor, A.; Shintani, Y.; Collino, M.; Osuchowski, M.F.; Busch, D.; Patel, N.S.; Sepodes, B.; Castiglia, S.; Fantozzi, R.; Bishop-Bailey, D.; et al. Protective role of peroxisome proliferator-activated receptor- $\beta / \delta$ in septic shock. Am. J. Respir. Crit. Care Med. 2010, 182, 1506-1515. [CrossRef] [PubMed]

182. Dunn, S.E.; Bhat, R.; Straus, D.S.; Sobel, R.A.; Axtell, R.; Johnson, A.; Nguyen, K.; Mukundan, L.; Moshkova, M.; Dugas, J.C.; et al. Peroxisome proliferator-activated receptor delta limits the expansion of pathogenic Th cells during central nervous system autoimmunity. J. Exp. Med. 2010, 207, 1599-1608. [CrossRef] [PubMed]

183. Paterniti, I.; Mazzon, E.; Riccardi, L.; Galuppo, M.; Impellizzeri, D.; Esposito, E.; Bramanti, P.; Cappellani, A.; Cuzzocrea, S. Peroxisome proliferator-activated receptor $\beta / \delta$ agonist GW0742 ameliorates cerulein- and taurocholate-induced acute pancreatitis in mice. Surgery 2012, 152, 90-106. [CrossRef]

184. Djouad, F.; Ipseiz, N.; Luz-Crawford, P.; Scholtysek, C.; Krönke, G.; Jorgensen, C. PPAR $\beta / \delta$ : A master regulator of mesenchymal stem cell functions. Biochimie 2017, 136, 55-58. [CrossRef] [PubMed]

185. Michelet, X.; Dyck, L.; Hogan, A.; Loftus, R.M.; Duquette, D.; Wei, K.; Beyaz, S.; Tavakkoli, A.; Foley, C.; Donnelly, R.; et al. Metabolic reprogramming of natural killer cells in obesity limits antitumor responses. Nat. Immunol. 2018, 19, 1330-1340. [CrossRef] [PubMed] 
186. Fan, W.; Waizenegger, W.; Lin, C.S.; Sorrentino, V.; He, M.X.; Wall, C.E.; Li, H.; Liddle, C.; Yu, R.T.; Atkins, A.R.;

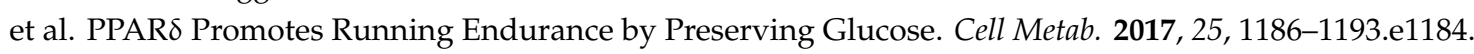
[CrossRef]

187. Narkar, V.A.; Downes, M.; Yu, R.T.; Embler, E.; Wang, Y.X.; Banayo, E.; Mihaylova, M.M.; Nelson, M.C.; Zou, Y.; Juguilon, H.; et al. AMPK and PPARdelta agonists are exercise mimetics. Cell 2008, 134, 405-415. [CrossRef]

188. Wang, Y.X.; Lee, C.H.; Tiep, S.; Yu, R.T.; Ham, J.; Kang, H.; Evans, R.M. Peroxisome-proliferator-activated receptor delta activates fat metabolism to prevent obesity. Cell 2003, 113, 159-170. [CrossRef]

(C) 2020 by the authors. Licensee MDPI, Basel, Switzerland. This article is an open access article distributed under the terms and conditions of the Creative Commons Attribution (CC BY) license (http://creativecommons.org/licenses/by/4.0/). 